IZA DP No. 5279

Risk Attitudes and Well-Being in Latin America

Juan Camilo Cardenas

Jeffrey Carpenter

October 2010 


\title{
Risk Attitudes and Well-Being in Latin America
}

\author{
Juan Camilo Cardenas \\ CEDE, Universidad de los Andes
Jeffrey Carpenter
Middlebury College
and IZA
Discussion Paper No. 5279
October 2010

\author{
IZA \\ P.O. Box 7240 \\ 53072 Bonn \\ Germany \\ Phone: +49-228-3894-0 \\ Fax: +49-228-3894-180 \\ E-mail: iza@iza.org
}

\begin{abstract}
Any opinions expressed here are those of the author(s) and not those of IZA. Research published in this series may include views on policy, but the institute itself takes no institutional policy positions.

The Institute for the Study of Labor (IZA) in Bonn is a local and virtual international research center and a place of communication between science, politics and business. IZA is an independent nonprofit organization supported by Deutsche Post Foundation. The center is associated with the University of Bonn and offers a stimulating research environment through its international network, workshops and conferences, data service, project support, research visits and doctoral program. IZA engages in (i) original and internationally competitive research in all fields of labor economics, (ii) development of policy concepts, and (iii) dissemination of research results and concepts to the interested public.
\end{abstract}

IZA Discussion Papers often represent preliminary work and are circulated to encourage discussion. Citation of such a paper should account for its provisional character. A revised version may be available directly from the author. 
IZA Discussion Paper No. 5279

October 2010

\section{ABSTRACT \\ Risk Attitudes and Well-Being in Latin America*}

A common premise in both the theoretical and policy literatures on development is that people remain poor because they are too impatient to save and too risk averse to take the sort of chances needed to accumulate wealth. The empirical literature, however, suggests that this assumption is far from proven. We report on field experiments designed to address many of the issues confounding previous analyses of the links between risk preferences and well-being. Our sample includes more than 3,000 participants who were drawn representatively from six Latin American cities: Bogotá, Buenos Aires, Caracas, Lima, Montevideo, San José. In addition to the experiment which reveals interesting cross-country differences, participants completed an extensive survey that provides data on a variety of well-being indicators and a number of important controls. Focusing on risk preferences, we find little evidence of robust links between risk aversion and well-being. However, when we analyze the results of three treatments designed to better reflect common choices made under uncertainty, we see that these, more subtle, instruments correlate better with wellbeing, even after controlling for a variety of other important factors like the accumulation of human capital and access to credit.

JEL Classification: C91, C93, D03, D81, O12

Keywords: risk aversion, ambiguity aversion, loss aversion, risk pooling, well-being, Latin America

Corresponding author:

Jeffrey P. Carpenter

Department of Economics

Middlebury College

Middlebury, VT 05753

USA

E-mail: jpc@middlebury.edu

\footnotetext{
* We thank Hugo Nopo and the Inter-American Development Bank for funding these experiments and the following researchers who made the field work possible: Martin Benavides, Natalia Candelo, Juan Jose Diaz, Nestor Gandelman, Saul Keifman, Nathan Lederman, Giorgina Piani, Sandra Polania and Arodys Robles. We also benefitted greatly from discussions with Peter Matthews on the design of the experiments and with Caitlin Myers on econometric issues. Lastly, the paper was improved by the thoughtful comments of Abigail Barr and Erin Krupka.
} 


\section{Introduction}

In 1930, Irving Fisher made a bold claim that has often been taken as a matter of fact in the policy and academic literatures on economic development ever since. He claimed that, to paraphrase, people remain poor because their inherent preferences are incompatible with growth (Fisher, 1930; Thaler, 1997). Since then discussions about attitudes towards risk (Pratt, 1964; Arrow, 1965) have caused the conjecture to morph into a statement often associated with the "culture of poverty": people remain poor because they are too impatient to save and too risk averse to take the sort of chances needed to accumulate wealth.

Despite early economic experiments that found no significant link between the risk preferences of poor farmers and wealth (Binswanger, 1980; Sillers, 1980; Walker, 1980) and, that "poor" rats tended to actually have lower discount rates in an innovative animal study that exhibited the sort of internal validity not attainable in human studies (Kagel et al., 1995), this conjecture continues to be the basis of economic models (Lipton, 1968; Katz and Stark, 1986; Netting, 1993; Banerjee, 2000; Azariadis et al., 2005) and policy (Adubi, 1996; Holzmann and Jorgensen, 1999; Sinha and Lipton, 1999; Knight et al., 2003).

The importance of this claim about the characteristics of the poor has caused it to gather considerable empirical attention. In the economics literature, the empirical tests of the conjecture can be divided into three categories. In one category, researchers begin by inferring preferences from observed choices and then these preferences are correlated with wealth or other measures of well-being. The results of this literature are mixed: some researchers find the poor to be more impatient (Lawrance, 1991) and risk averse (Moscardi and de Janvry, 1977; Rosenzweig and Wolpin, 1993) but others find no link between wealth and discount rates (Ogaki and Atkeson, 1997) and that the self-employed are actually more risk averse (Halek and Eisenhauer, 2001).

The first method has been criticized because wealth or its correlates enter both stages of the analysis and this might lead to spurious correlation (Lybbert and Just, 2007). This, however, is not a problem for the second method which relies on direct measures of preferences from surveys. Researchers in this category report that people with higher incomes are less risk averse (Donkers et al., 2001; Hartog et al., 2002) and more patient (Ashraf et al., 2006; Holden et al., 1998).

While the second method does not suffer from the spurious correlation problem, the preference measures are based on hypothetical questions which might be more prone to various forms of measurement error (Bertrand and Mullainathan, 2001). The third method of testing the conjecture suffers from neither of these issues. The third group of researchers conducts incentivized experiments to elicit preferences. In these experiments real money is at stake 
and participants have the incentive to truthfully reveal their preferences. Concerning impatience, some researchers in India and Canada find the poor to be more impatient (Pender, 1996; Eckel et al., 2005) but this does not appear to be true in Denmark (Harrison et al., 2002). In Ethiopia, one study reports the poor to be more risk averse (Yesuf and Bluffstone, 2007) but the opposite holds in Spain (Bosch-Domenech and Silvestre, 2006) and among poor farmers in Chile and Tanzania (Henrich and McElreath, 2002).

A related problem with measures of risk and time preferences is that it is no longer appropriate to gather just the "standard" measures. Instead of being risk averse, it might be, for example, that the variation in attitudes towards potential losses (Kahneman and Tversky, 1979) or the aversion to ambiguous situations (Ellsberg, 1961) matters. Concerning patience, some researchers are now convinced that people have time inconsistent preferences. The hyperbolic discounting model suggests that people appear to be much more impatient about decisions with immediate consequences than they are when they think about similar decisions scheduled to take place in the future (Angeletos et al., 2001).

Aside from the measurement problems with time and risk preferences already mentioned, there are other problems that make it difficult to say anything definitive about the relationship between preferences and well-being. Although incentivized experiments may provide the best quality data on preferences, samples from the lab tend to be small and from convenience samples of college students which usually lack variation in the important socio-economic characteristics in which we are interested. Even if one is confident in the quality of the data and can gather enough to be credible, the relationship between preferences and well-being may also be complicated by other factors such as the availability of credit (Stiglitz, 1989).

We report on field experiments designed to address a number of the problems confounding previous analyses of preferences and well-being. In this project we focus on the relationship of experimental risk attitudes, including aversions to losses, ambiguity, the willingness to pool risks with others and a spectrum of well-being measures (home ownership, basic services, employment, overall economic status, perceived relative economic status, requiring government assistance, expenditures and having lost a business). Our participants faced real monetary incentives earning the equivalent of two days pay, on average, in 159 sessions. Our sample is the most extensive and complete assessment of risk attitudes in Latin America gathered to date; it includes more than 3,000 participants who were drawn representatively from six Latin American cities: Bogotá, Buenos Aries, Caracas, Lima, Montevideo, San José. In addition to the experiment, participants completed an extensive survey that provides a number of important controls for our analysis including demographics and their access to credit.

As a preview, we first show that our experimental procedures replicate many of the 
stylized fact in the related literature: risk attitudes are varied but most people react more conservatively when the lotteries become ambiguous and less conservatively when losses are involved. These results continue to hold when we look for city-level differences; however, we also find that there is significantly more risk taking in Caracas than in any other city.

Considering the links between risk-taking and outcomes, we find no robust association between baseline risk attitudes and our measures of well-being. While it is tempting to consider this an indictment of the "Fisher hypothesis", we show that interesting associations do arise when we examine the effects of our treatments on baseline risk attitudes. When the experiment is changed so that the decision problem is more ambiguous, we find that people who react extremely to ambiguity tend to have lower wealth and fewer basic services (e.g., running water). Somewhat in contrast, those people who react more risk aversely when losses become possible have higher home ownership rates, more basic services, and perceive themselves as having higher wealth. Our most robust experimental manipulation, however, is when we allow participants to pool risk. Here, among other correlations, we see that those participants that do not understand the advantage of pooling risk are less likely to own their homes, have basic services and are more likely to need government assistance to get by.

\section{Experimental Design}

We discuss four components of a larger set of experiments that took place in six Latin American capital cities during the spring of 2007. A number of the other components are discussed in Calonico et al. (2007). Representative samples of individuals from heterogeneous urban societies in Bogotá, Buenos Aries, Caracas, Lima, Montevideo and San José were recruited in the streets and invited to participate voluntarily in a set of economic experiments with actual and salient economic incentives that averaged about what a worker could get for $1 \frac{1}{2}$ - 2 days of work at the minimum wage, or US\$10-12 per participant.

Four lottery choices gave us the information necessary to assess participant attitudes towards risk, ambiguity, losses and risk-pooling. In each case, a participant was shown a ring of six possible binary lotteries and asked to pick one to play. To minimize any problems that the participants might have with understanding and assessing probabilities (Kahneman et al., 1982), the likelihood of good and bad outcomes were equal in each task. Figure 1 displays a version of the baseline graphic used in the field that has been redrawn with dollar payoffs proportional to the field payoffs. The payoffs for each 50-50 lottery were chosen so that the expected payoff of each lottery increases as one moves clockwise (from $\$ 33$ to $\$ 47.5)$, but so does the variance of the payoffs. This pattern is only violated as one moves from the $\$ 4 \mid \$ 91$ lottery to the $\$ 0 \mid \$ 95$ lottery. Here the expected value does not change but 
the variance continues to increase. Using the constant relative risk aversion utility function, $U(x)=\frac{x^{1-r}}{1-r}$ to evaluate the risk attitudes at which people should be indifferent between any two neighboring lotteries we find that the coefficient of relative risk aversion $r$ that would make one indifferent between the first and second lotteries, for example, will solve:

$$
\begin{aligned}
U(33) & =\frac{1}{2} U(25)+\frac{1}{2} U(47) \\
\frac{33^{1-r}}{1-r} & =\frac{1}{2}\left(\frac{25^{1-r}}{1-r}\right)+\frac{1}{2}\left(\frac{47^{1-r}}{1-r}\right)
\end{aligned}
$$

The cutoffs, therefore, are the following: picking $\$ 33 \mid \$ 33$ indicates extreme risk aversion, $r>1.77$. Picking $\$ 25 \mid \$ 47$ indicates $0.82 \leq r \leq 1.77, \$ 18 \mid \$ 62$ indicates $0.48 \leq r \leq 0.82$, $\$ 11 \mid \$ 77$ indicates $0.28 \leq r \leq 0.48, \$ 4 \mid \$ 91$ indicates $0 \leq r \leq 0.28$, and picking $\$ 0 \mid \$ 95$ indicates $r \leq 0$ or possible risk seeking.

The lotteries were implemented in the field using bags of balls. The participants were told that they were to choose a lottery from the ring and that each lottery represented a bag with ten balls inside. Each of the six bags was comprised of five high value balls and five low value balls. Once the participant chose a lottery, she then blindly picked a ball from the corresponding bag and earned the payoff from this choice.

Participants then make choices from three rings where the setup is slightly altered. In the ambiguity treatment, the possible outcomes of the lotteries are the same but the chances of either the good or bad outcome are uncertain. Instead of six bags with five high and five low value balls for sure, participants were told that each bag had three high value balls and three low value balls for sure, but they were not told the distribution of the remaining four balls. This meant that the probability of the good outcome was uncertain; it was somewhere between $3 / 10$ and $7 / 10$. This choice was presented to the participants using the graphic in Figure 2 .

In the loss treatment, motivated by prospect theory (Kahneman and Tversky, 1979), participants began with an endowment of $\$ 50$ and then chose from the six lotteries in Figure 3. As one can see, if you add $\$ 50$ to each payoff, you get back to the baseline, Figure 1. This means that the only thing that has changed is the framing of the decision problem. The purpose is to investigate whether participants react differently when losses are possible compared to the baseline.

In the Pooling treatment, participants reconsidered the decision task in Figure 1 only this time they were asked if they wanted to pool their risk. Specifically, participants were told that they could join a pooling group in which all the payoffs from the poolers would be combined and each pooler would get a $1 / n$ share of the total earnings. If they decided to 
not pool, the game was identical to a replay of the baseline. The order of decisions was as follows: decide to pool or not, learn the number of poolers in the group, decide on a lottery from Figure 1 without communicating with each other. In this treatment we examine if people are willing to join an insurance program and if they respond optimally to the fact that risks are now pooled when they make their lottery choices.

Clearly risk averse participants should decide to pool in the last treatment. Given the outcomes of the lotteries are completely independent, the probabilities of really good and really bad outcomes fall, even in groups of two. In other words, even though the expected payoff will not change, risk will fall for poolers. Consider two-person groups as an illustration. Going it alone, the moderately risk averse person who picks the $\$ 18 \mid \$ 62$ in the baseline and must have $0.48 \leq r \leq 0.82$ earns expected utility of $\frac{1}{2}\left[\left(18^{1-r}\right) /(1-r)\right]+\frac{1}{2}\left[\left(62^{1-r}\right) /(1-r)\right]$ which will be lower than what she plans on receiving in a two-person group, $\frac{1}{4}\left[\left(18^{1-r}\right) /(1-\right.$ $r)]+\frac{1}{2}\left[\left(40^{1-r}\right) /(1-r)\right]+\frac{1}{4}\left[\left(62^{1-r}\right) /(1-r)\right]$, for any allowable $r$.

The seemingly harder decision problem is which lottery to pick once one has joined a pooling group. The first thing to notice, however, is that because the pooling arrangement will force everyone to have the same payoff in the group, strategic motivations are mute and the problem is the same as what a social planner would choose. If we maintain the same two-person group example and assume common knowledge of symmetric underlying risk attitudes, the predictions of what choices participants should make is relatively straightforward. Given our parameterization, a simple heuristic arises: compared to your first risky choice, if you pool, pick the next riskiest lottery. A group of two players who chose $\$ 11 \mid \$ 77$ in the baseline, for example, would do best to pick $\$ 4 \mid \$ 91$ in the pooling task and the logic is simple. If pooling reduces our risk a little, our preferences should cause us to compensate by picking a lottery with slightly more risk and higher expected value.

At the end of the last activity one of the four activities was randomly selected to be paid, and while one monitor calculated individual earnings and called each of the participants for payment (privately), the rest of the monitors interviewed the participants for detailed information about their background and opinions towards various dimensions of social exclusion.

One advantage of our sample, other than size, is that we strove to make the city subsamples representative. Other studies have looked cross-culturally (Henrich et al., 2001; Henrich et al., 2006) at samples from mostly isolated small-scale societies, or samples of college educate people in urban settings (Herrman et al., 2008). We went to great lengths to stratify our sample based on economic position, education, gender and age in large urban Latin American cities.

To reduce any idiosyncratic errors that might result from variation in the participants' ability to read, the post-experiment surveys were administered by a group of hired pollsters 
trained for this purpose. Each city team agreed to sample more than 500 participants from their cities, and conduct more than 25 sessions. The local team in each city designed a stratified sample from the population of their cities, based on socio-economic class, education, gender and age as criteria. In the end 3109 people participated in the six cities providing a unique data set that combines detailed data from their socio-economic and demographic background with behavioral data from their decisions during the experiments. This is, as far as we know, the most comprehensive experimental dataset gathered for Latin America given the number of countries included, the completeness of the demographics, the sample sizes and the replicability of the designs in each city.

Each of the city teams conducted sessions of various group sizes from 9 to 38 people with a mean size of 22 people in each session. All of the sessions followed a common protocol with the same sequence of activities. The measures of well-being that we collected were listed above and Table 1 summarizes, by city, the features on which the samples were stratified, along with other information about our participants. Most of the variables are intuitive; however, some require more description. Because incomes, wealth and instances of poverty differ by city, we normalized each participant's Socio-economic Class into one of three economic classes: low status, middle status, high status. This categorization was based on the social stratification used by each city for classifying neighborhoods by income. These stratifications are used when assigning utility rates (e.g., electricity), for example with the goal of charging higher rates to higher income neighborhoods thus subsidizing low income neighborhoods. However, some cities have more categories than others: Buenos Aires and San José have three categories, Caracas and Montevideo have four, Lima has five and Bogotá has six. To make these comparable across cities, we grouped levels for cities that had more than three levels into the respective low, middle and high socio-economic classes.

College is an indicator for education and takes the value of 1 if the participant has achieved a college degree or more education. The two Heritage indicators are 1 if the participant selfreports indigenous or African ancestry. We measure two characteristics of the participant's home. Home Size is measured by the number of bedrooms and we measure the earning power of the household by asking for the number of Income Earners in the home. Lastly, we ask two questions about socio-economic exclusion. No Access to Credit is an indicator which is 1 if the participant has not been able to get a loan in the past five years and No Access to Politics takes the value 1 if the participant has been excluded from participating in the political process in the past five years.

With the help of Table 1, we can summarize our participants. Overall our participants were $56 \%$ female, $31 \%$ were married, only $2 \%$ had been to college, $2 \%$ revealed indigenous heritage and another $2 \%$ claimed African heritage. In addition, $23 \%$ said that they had no 
access to credit, if needed but only $4 \%$ said they had absolutely no access to the political process; in other words, surprisingly few felt completely disenfranchised. On average, our participants were 37 years old, they had slightly more than one child and they lived in homes with about two and a half bedrooms and two income earners.

\section{An Overview of the Experimental Data}

Considering the lottery choices, our results appear to be in accordance with previous studies (e.g., Binswanger, 1980 or Barr and Genicot, 2008): all of the lotteries are chosen to some degree but some are clearly chosen more often than others. ${ }^{1}$ In the risky baseline, the modal choice is $\$ 25 \mid \$ 47$ which demonstrates considerable risk aversion. Ordering the lotteries clockwise from one to six, the average choice in the baseline is 2.80 which puts the average closest to the $\$ 18 \mid \$ 62$ gamble.

Based on the pseudo-experiment conducted by Ellsberg (1961) and the subsequent work, we expected that participants would react, on average, more conservatively (i.e., risk aversely) in the ambiguous choice treatment. Indeed, there is some shift from the more risky lotteries to the less risky ones in the ambiguity treatment. Although the shape of the distribution does not change dramatically, the average choice falls to 2.66 which is statistically significant $(t=5.26, p<0.01)$ because of the large size of our sample. Indeed, ambiguity causes the average participant to choose "safer" lotteries.

Prospect theory (Kahneman and Tversky, 1979) posits that losses are treated differently than gains. In particular, anchored at some reference point people tend to be more risk seeking in the loss domain than in the gain domain. We see that our loss treatment triggers substantial movement towards riskier lotteries. The average choice climbs to 3.23 which is again highly significant $(t=12.99, p<0.01)$ compared to the baseline. The distribution of choices also changes substantially. There appears to be more bifurcation in the loss choice distribution: the mode is the safe $\$ 33 \mid \$ 33$ lottery but there is now, compared to the baseline, more than twice as many people choosing the $\$ 0 \mid \$ 95$ lottery.

As suggested above, pooling should cause people to choose more risky lotteries because the reduced risk associated with the insurance can be offset by choosing lotteries with higher expected values. Indeed, the average choice is 2.86 which is higher (more risk seeking) than the baseline but the difference is only significant at the $5 \%$ level $(t=2.16, p=0.03)$. At the same time, if we consider only those participants who chose to pool, the average choice is 2.94 and the difference is highly significant $(t=3.62, p<0.01)$.

\footnotetext{
${ }^{1}$ As hoped we found considerable variation in the lotteries chosen in the baseline risk task: $23 \%$ of participants "played it safe" and chose $\$ 33$ for sure, 30\% picked the $\$ 25 \mid \$ 47$ lottery, $19 \%$ picked $\$ 18 \mid \$ 62$, $11 \%$ picked $\$ 11 \mid \$ 77,8 \%$ picked $\$ 4 \mid \$ 91$ and the remaining $9 \%$ picked $\$ 0 \mid \$ 95$.
} 
Given the breadth of our study, we can also disaggregate our data to see if choices vary by location. Figure 4 presents pie charts to summarize the lottery choice data by treatment and city. In panel (a) we confirm that the $\$ 25 \mid \$ 47$ gamble is the modal choice in the baseline risk instrument for more than half of the cities. While there appears to be variation across cities (e.g., more than half of the choices in Buenos Aires, Montevideo and San José were for one of the two safest lotteries while $\$ 18 \mid \$ 62$ was a common choice in Bogota and Lima), using the simple system of assigning integers to the lotteries and calculating t-statistics suggests that the only strong result is that the participants in Caracas picked significantly more risky lotteries than in any other location ( $p<0.01$ for each comparison). This basic result is confirmed by the ordered probit regressions reported in the appendix (Table A1) where we also control for the individual characteristics summarized in Table 1. Focusing on the safe choice, we see that Venezuelan participants are $6.2 \%$ less likely to pick the $\$ 33 \mid \$ 33$ lottery than the Colombian participants $(p<0.01)$, a result that is repeated for all the other comparisons with Caracas (at $p=0.02$ or better).

There appears to be more variation by location in panel (b) of Figure 4 which illustrates the choices when the probabilities are ambiguous. It is still the case that the choices in Caracas are more risk seeking than in the other locations and the differences are significant according to t-tests (at $p<0.01$ ) with one exception: choices in the ambiguity task do not appear to differ between Caracas and San José, perhaps because participants in San José did not react as strongly to ambiguity as the other participants did. This lack of a Costa Rican response to ambiguity also means that differences arise between San José and two other locations, Bogotá and Buenos Aries ( $p<0.01$ in both cases). We find corroborating evidence in Table A1 which shows that Venezuelan participants were $9.9 \%$ less likely $(p<0.01)$ and Costa Rican participants were 4.9\% $(p<0.10)$ less likely to pick the safe $\$ 33 \mid \$ 33$ lottery than were the Colombian participants.

In panel (c) of Figure 4 we report the city-level choices from the instrument that allowed losses. This appears to be the treatment where the largest differences emerge between cities. Not only are the choices in Caracas more risky than in Bogotá $(p=0.02)$, Buenos Aries $(p<0.01)$ and San José $(p=0.07)$ according to simple t-tests, San José also appears more conservative with losses than Montevideo $(p=0.08)$ and less conservative than Buenos Aries $(p=0.07)$. Further, participants in Buenos Aires take fewer risks with losses than both Lima $(p=0.01)$ and Montevideo $(p<0.01)$ and the participants in Montevideo also take more risks than those in Bogotá $(p=0.02)$. Table A1 suggests that Venezuelan decision makers are $5 \%(p<0.05)$ less likely to pick the safe $\$ 33 \mid \$ 33$ lottery than their Colombian counterparts and that the point estimates are also significantly different between Buenos Aires and Caracas $(p<0.01)$, Lima $(p<0.10)$, and Montevideo $(p<0.01)$. 
Lastly, we present the results from the risk pooling treatment in panel (d) of Figure 4. As noted above, overall people tend to choose slightly riskier lotteries in this treatment, as they should to take advantage of the pooled risk. The city-level responses to pooling seem remarkably homogenous across cities because exactly the same differences that arose in panel (a) are significant in panel (d). Specifically, participants in Caracas chose more risky lotteries in the pooling treatment than in any other location according to simple t-statistics (the highest p-value was 0.07 in the comparison with Bogotá) and the other differences are not significant. While the coefficient on Caracas is not significant in Table A1, the difference in point estimates between Buenos Aries and Caracas is significant $(p=0.03)$ after controlling for individual characteristics. ${ }^{2}$

It is easier to visualize individual differences between the treatments by taking differences. To create a measure of "ambiguity aversion" we again order the lotteries one through six and take the difference in behavior between the ambiguity treatment and each player's baseline risky choice. If the difference (ambiguity-risk) is negative the participant behaves more cautiously in ambiguous situations and if it is positive she is more risk seeking under uncertainty. We created a measure of "loss aversion" by taking the difference between the second treatment and the baseline (loss-risk). People are loss averse (i.e., the difference is positive) in the sense that they shy away from certain losses and, in doing so, are willing to incur more risk when losses are possible. For the risk pooling behavior in the last task we created the willingness to take on risk when pooling by calculating the difference between the pooling response and the baseline (pooling-risk). People respond "optimally" by taking on more risk once they have chosen to pool, particularly if they increase the risk by one lottery.

In Figure 5 we summarize the city-level differences in our three more nuanced measures of risk-taking behavior. On average, people in all six cities tend to make different, but consistent, choices in the treatments. Ambiguity generates a relatively homogeneous response (blue circles). People tend to be more risk averse when the situation is ambiguous (ambiguitybaseline $<0$ ) and this tendency is similar in all the locations although the difference between our participants from Bogotá and those from San José is significant $(t=2.34, p=0.02)$. There also tends to be a behavioral difference when losses are at stake. In accordance with previous findings (Tversky and Kahneman, 1981), people tend to be more risk seeking when losses are at stake (i.e., they shy away from certain losses). Compared to the ambiguity difference, people tend, in all locations, to be relatively more averse to certain losses and there seems to be more variation in this response by location. The citizens of Montevideo

\footnotetext{
${ }^{2}$ There is one other robust finding to note from Table A1. Female participants were between $3.4 \%$ and $5.9 \%$ more likely to chose the safe $\$ 33 \mid \$ 33$ lottery in each of the treatments ( $p<0.01$ in all cases).
} 
appear to be extremely loss averse compared to those from Buenos Aires which is strange considering the proximity of the two experimental locations. Lastly, we also see that, on average, people react as expected to the risk pooling treatment. If they pool, they then tend to pick riskier lotteries. This result becomes even more interesting when we recall that the risk-pooling decision was made in private, without coordinating or communicating with the rest of the group. Further, pooling tends to generate the most homogeneous response across cultures. ${ }^{3}$

\section{Simple Risk and Well-being}

The first step in our analysis is to replicate what others have done: does our measure of risk aversion correlate with well-being? In Figure 6 we introduce two of our well-being measures. In the top panel, we assess the likelihood of being in the top of three "economic classes" (EC) as a function of the participant's lottery choice. In the bottom panel of Figure 6 we create a similar graph using "relative wealth" (RW) instead of economic class. Our relative wealth measure is novel in that we asked each participant to imagine where she stood on an economic ladder with ten rungs (so that those at the top of the economy were on the tenth rung). In other words, what was the participant's evaluation of her relative economic position in society? Combined, these two measures of well-being give us objective and subjective rankings. Further, these measures are correlated, both overall and at the city level. The $95 \%$ confidence intervals of the 1 to 10 subjective scale for each objective class are $[3.92,4.17]$ for the low class, $[4.94,5.09]$ for the middle class and $[5.80,6.03]$ for the upper class.

According to the conjecture that motivates our work, the bar height in the two panels of Figure 6 should increase from left to right because the gambles are arrayed from extremely risk averse $(\$ 33 \mid \$ 33)$ to risk neutral or risk seeking $(\$ 0 \mid \$ 95)$ and more risk tolerant people should be better off. Although the top panel of Figure 6, which uses economic class, appears to roughly conform to the conjecture in that the two highest risk gambles are associated with higher probabilities of being in the upper class, the bars associated with the $95 \%$ confidence intervals hint that not many of these differences are statistically significant. In addition, the bottom panel, in which subjective evaluations are used, demonstrates tighter confidence intervals but the differences in the means are also smaller. So, again, there does not appear, based on simple tests, to be a significantly increasing relationship between one's tolerance for risk and well-being.

\footnotetext{
${ }^{3}$ Although a few demographics (e.g., gender and having children) are robustly associated with the behavioral differences driven by our treatments, to not distract from the main point of our analysis, we simply present a table of regression results in the appendix (Table A2) for the interested reader.
} 
Adding six more measures of well-being and using multiple regressions to control for other factors that might explain some of the variance in economic outcomes, makes our first step analysis more comprehensive. To economic class and relative wealth, we add a variety of measures that broaden the analysis from wealth to well-being, more generally. The inclusions are an indicator for home ownership (56\% affirmative), an indicator for participants who report having all three basic services: electricity, piped water, trash collection (93\% affirmative), an indicator for being employed ( $58 \%$ affirmative), the level of family expenditures measured as multiples (1-7) of the local minimum wage, an indicator for not receiving any government assistance (64\% affirmative) and an indicator for never having lost a business to bankruptcy ( $94 \%$ affirmative). The last two measures were transformed to have the same, positive, frame as the others.

Methodologically, our regression strategy was to be as agnostic as possible about the specification by creating indicator variables for each of the six lotteries. If the data conform to the conjecture that people who are more tolerant of risk are better off then we should see that the coefficients on the lottery indicators are increasing in magnitude as the lotteries represent more risk tolerance (just like the bar heights should have increased monotonically in Figure 6).

Table 2 summarizes the results of eight regressions (which are reported in detail in the appendix, Table A3) and multiple coefficient comparisons. ${ }^{4}$ The lottery choices are arrayed along the top and side of the table. The acronyms entered in the table indicate the domain for which the regression was run. NRA, for example, indicates the regression in which the indicator for not requiring government assistance was the dependent variable. All entries indicate that the coefficient on the row lottery was statistically significantly greater (at the $10 \%$ level or better) than the coefficient on the column lottery. Thus, entries below the diagonal are consistent with more risk tolerance being associated with higher well-being. At the same time, entries above the diagonal are evidence of the opposite trend: greater risk tolerance being associated with lower well-being.

Overall, the evidence in Table 2 suggests that there is almost as much evidence that well-being decreases with risk tolerance as there is suggesting the opposite. There are a few domains of well-being that seem to be most in line with the conjecture. When not receiving government assistance (NRA) is the dependent variable, one more risky lottery $(\$ 25 \mid \$ 47)$

\footnotetext{
${ }^{4}$ For the binary outcome variables (home ownership, employment, not requiring government assistance, having not lost a business) the regressions use the probit estimator. For the basic services and economic class regressions ordered probit is used and the marginal effects for being in the highest group (having all three basic services or being in the highest of three classes) are reported. Because the dependant variable is truncated at one and ten in the case of relative wealth and at one and seven for expenditures as multiples of minimum wages, we use the tobit estimator in these two cases. In each case, the standard errors are clustered at the session level.
} 
has a greater coefficient than the baseline, safe $\$ 33 \mid \$ 33$ lottery. While not all the coefficients are significantly different, after controlling for other factors, Table 2 indicates that there is some evidence that the well-being measures depicted in Figure 4 (EC and RW) increase with risk-taking. However, considering the entries for EC and RW above the diagonal, it might be that the relationship is not monotonic; a U-shape seems to be a slightly better fit. Very risk averse people and risk-neutral people do the best economically, those with moderate risk aversion may do worse. Nevertheless, these results should not be overstated because there are many empty cells in Table 2 suggesting that the significant differences are not terribly robust. In sum, with a very large sample and a lot of important controls we find only limited evidence for the conjecture that more risk tolerance corresponds to higher well-being.

At the same time, a closer inspection of the full regressions reported in appendix Table A3 reveals interesting correlations between some of our controls and the outcome measures.

Of most interest, perhaps, is that social exclusion, measured in our case as not getting loans or not having access to political campaigns is associated with lower well-being. The strong effect of credit is particularly interesting because it is a factor that we deemed important to control for and is often absent from tests of the relationship between preferences and outcomes. Additionally, it is not surprising (but confirming of our survey) to find that in five of the eight domains, having a college education or more is associated with higher well-being.

\section{$5 \quad$ Ambiguity, Losses, Risk Pooling and Well-being}

As hinted at in the introduction, we can take another, more nuanced, second step in our analysis because of the additional treatments we conducted to identify several biases that now regularly appear in the empirical and theoretical decision-making literatures. Perhaps it is not simple risk aversion that correlates with well-being; maybe biases that arise as the decision environment gets closer to the sort of conditions encountered in real life will be more closely associated with well-being. Few real world decisions, apart from those encountered in the casino, involve pure risk. Instead of knowing all the possible outcomes and the probabilities associated with those outcomes, many decisions are made under uncertainty when the important parameters are ambiguous - you often do not know what the chances of an outcome occurring are for sure (e.g., Engle-Warnick et al., 2008). In addition, real world lotteries usually involve both gains and losses and it is now reasonable to expect that people treat losses differently from gains. Lastly, people in the real world occasionally make risky choices as part of a group instead of alone. Having groups set up insurance schemes by pooling their risky choices should cause individuals to reconsider their individual choices. 
If there is no clear relationship between simple, more traditional, measures of risk aversion and economic outcomes, do the more nuanced measures correlate better? In Table 3 we report the results of a conservative test of the extent to which these additional preference measures are associated with well-being. The results are conservative in that we control for a number of other factors, we cluster standard errors at the session level to account for the idiosyncrasies that may occur during individual sessions and, despite the resulting inflated standard errors due to possible multicolinearity, we force the three measures to compete "head-to-head" to explain the variation in well-being.

Following Klibanoff et al. (2005) who argue that ambiguity aversion can only be understood in reference to one's risk aversion, we use the difference in behavior between the treatments and the risky baseline as our preference measures. We also allow for the relationship between preferences and outcomes to be "kinked" by using a spline specification. Instead of assuming that the relationship between preferences and outcomes will be the same regardless of whether people act more or less conservatively to the treatments, we allow the slope to change at the origin. Hence, there are six independent variables of interest reported in Table 3: accepting less or more risk in the treatment compared to the baseline for each of the three treatments. Specifically, for each of the well-being measures, $W B_{i}$, we use the following specification:

$$
\begin{aligned}
W B_{i}= & \beta_{0}+\beta_{1}\left(\text { Ambiguity }_{i}-\text { Risk }_{i}\right)+\beta_{2} \max \left\{\text { Ambiguity }_{i}-\text { Risk }_{i}, 0\right\} \\
& +\beta_{3}\left(\text { Loss }_{i}-\text { Risk }_{i}\right)+\beta_{4} \max \left\{\text { Loss }_{i}-\text { Risk }_{i}, 0\right\}+\beta_{5}\left(\text { Pool }_{i}-\text { Risk }_{i}\right) \\
& +\beta_{6} \max \left\{\text { Pool }_{i}-\text { Risk }_{i}, 0\right\}+\beta_{7} X_{i}+\epsilon_{i}
\end{aligned}
$$

where $X_{i}$ is a vector of controls and $\epsilon_{i}$ is an error term. Risk, Ambiguity, Loss, and Pool are the lottery choices ordered from no risk to possible risk seeking (i.e., clockwise from one to six) and the difference is the treatment effect. As in our discussion of Figure 5, Ambiguity-Risk is our measure of ambiguity aversion, Loss-Risk is our measure of loss aversion and Pool-Risk is our measure of the net effect of pooling on behavior. Because these measures can be positive or negative, the max portions of the specification allow those who are more conservative in the treatments (those for whom the difference is negative) to have different outcomes than those who behave more risk seeking in the treatments. To see this, simply think about the marginal effects. For someone who behaves more conservatively in the ambiguity treatment than in the baseline, the difference will be negative and the effect of this difference on well-being will be captured by $\beta_{1}$ alone because $\beta_{2}$ will be multiplied by zero. A person with a positive difference (who sought more risk under ambiguity) will have the effect $\beta_{1}+\beta_{2}$. 
The results of running these regressions for each of the eight well-being measures are collected in appendix Table A4. One will notice that these results are different from those reported in the Table 3 because we use the above specification to calculate the more intuitive point estimates of the sums $\beta_{1}+\beta_{2}, \beta_{3}+\beta_{4}$, and $\beta_{5}+\beta_{6}$ and standard errors, which again are clustered by session, reported in Table 3 .

As one can see, each of the domains of well-being appears to be associated with at least one of our preference measures. In this broad sense, the more nuanced protocols have already performed better than the standard risk measure. Instead of focusing on the details of Table 3 and the subtleties of each domain, can we recognize any broad patterns in these results? When it matters (Basic services, Relative wealth, Not requiring government assistance, Not having lost a business), one's estimated reaction to ambiguity tends to be associated concavely with well-being. For convenience, these relationships are graphed in Figure 7 where the horizontal axis of each graph measures the relative tolerance towards ambiguity against the baseline risk aversion measure. The thick solid red lines indicate that the slope is significantly different from zero at the $10 \%$ level or better and thin dashed black lines indicate insignificant effects. Figure 7 suggests that those people who react extremely to ambiguity, in either direction, are less well off. Specifically, people who reacted very conservatively in the ambiguity treatment compared to the baseline are less likely to have all the basic services and tend to have lower relative wealth. At the same time, those who react in a risk seeking manner when the gamble is ambiguous tend to get more government assistance and are more likely to have lost a business.

Reactions to losses, graphed in Figure 8, are also significantly correlated with well-being in four domains (Home ownership, Basic services, Relative wealth, Expenditures) and, in contrast to the ambiguity results, the relationship tends to be more convex. Now those at the extremes are better off. In particular, those participants who act more risk aversely when losses are at stake tend to have higher home ownership rates, more basic services and higher subjective assessments of their relative wealth.

As seen in Figure 9, one's behavioral difference in the risk pooling treatment is associated with well-being in all but one domain (having lost a business). Like ambiguity, the general relationship between pooling and well-being tends to be concave. Again, those at the extremes do worse. In particular, those who react contrary to theory have lower well-being. Recall that theory suggests that even risk averse poolers should pick the next risky lottery. Being more conservative in the pooling treatment (instead of more risk seeking) is associated with lower likelihoods of home ownership, having all the basic services, being in the highest class and requiring government assistance. These people also tend to have more modest assessments of their relative wealth and lower expenditures. 
Returning to Table 3 we see another important result that supports the validity of our indicators and introduces the possibility of institutional barriers along with the behavioral ones. Specifically, perceived limits to one's ability to get credit are also a strong predictor of well-being in six of our eight domains. Having limited access to credit correlates with being $5.4 \%$ less likely to own a home, $4.9 \%$ less likely to be in the highest of three economic classes, $5.9 \%$ more likely to need government assistance, $5 \%$ more likely to have lost a business to bankruptcy, and to have subjective assessments that are $7 \%$ less and $23 \%$ less than the average of one's relative income and of one's expenditures, respectively. ${ }^{5}$

\section{Discussion}

There is a long tradition in economics and public policy of assuming that people are poor because they have attitudes and preferences that keep them from saving and investing in projects that can improve their well-being. Our research takes aim at the assumed link between preferences and outcomes.

Our first step is to compile the most comprehensive sample of experimentally-induced risk attitudes in Latin America gathered to this point. Looking at summary behavior from this sample further suggests that our procedures are valid in that we replicate a number of standard biases found in the literature. Comparing across locations we find that our Venezuelan participant in Caracas tended to incur the most risk, our Colombian participant in Bogota reacted the most to ambiguity, our Uruguayan participants in Montevideo reacted most loss aversely, and the largest fraction of participants to react optimally to risk pooling occurred in Buenos Aries.

Our second step is to use a large sample of incentivized participants and a broader set of well-being measures to replicate previous results that have used standard risk aversion instruments. We find little evidence of robust links between risk aversion and well-being.

In our third step we analyze the results of three different treatments that add elements of reality to the decision problem to see if these, more subtle, instruments correlate better with well-being. Indeed they do, even after controlling for a variety of other important factors like human capital accumulation and access to credit. Not only are there significant links between responses to ambiguity, losses and pooling, the links array themselves in interesting patterns that should spark new areas of research. For example, we find that people with extreme relative reactions to ambiguity do worse. Of particular interest is that people who seek risk in ambiguous situations may tend to subject themselves and their families to too much risk

\footnotetext{
${ }^{5}$ As one can see, the returns to a college education also come through in Table A4. These people are $5 \%$ more likely to have all the basic services, $14 \%$ more likely to be employed, $41 \%$ more likely to be in the highest economic class and perceive themselves to have relatively more wealth and expenditures.
} 
in their daily lives because these people are more likely to need government assistance and are more likely to have lost a business.

Our loss and pooling results are equally interesting. Concerning behavioral responses to the possibility of losses, in studies conducted in labs on college campuses most people seek risk when losses are at stake. We replicate this in the field: $75 \%$ of our participants tolerated more or the same amount of risk in the loss treatment. However, while much of the focus of previous research has been on the majority of the population who seek risk, our findings suggest that it is the other participants, those that react very conservatively to losses, who are more interesting. These people are more likely to own their own homes, have a full set of basic services and perceive themselves to be of higher economic stature.

Our risk pooling results are interesting because they suggest that those participants who reduce their risk tolerance instead of increasing it, in other words those that do not take advantage of the insurance aspect of pooling, do significantly worse in five of the eight domains. This result alone seems important in the development context because so much attention has been paid to risk pooling strategies in rural agriculture and, taken alone, our risk pooling results should be the impetus for new research.

Finally, as interesting and important as the behavioral results are, another, more unintended, yet important, theme emerges in our data. While the primary goal of this project was to test the extent to which risk preferences and their more contextually relevant variants correlate with economic well-being, we also wanted to control for social exclusion, particularly one's access to credit. As it turns out, perceived credit hindrances appear to matter robustly and have effects that are (roughly) of the same magnitude as our behavioral results. Given preferences and credit access compete "head-to-head" in our analysis, these results go a long way to inform one standard critique of what we are calling the "Fisher hypothesis": that preferences do not matter, it is malfunctioning credit markets that may keep people poor. Indeed, in our data both preferences (albeit not simple risk preferences) and access to credit correlate with well-being, however, only credit access appears to do so robustly and systematically. This is particularly relevant for the context of developing countries where access to the formal banking sector remains limited. In this regard, our results suggest lessons about the use of financial mechanisms that seem to create Pareto enhancing behavior such as moderate increases in risk tolerance when risk can be pooled that might also have implications for the design of microfinance programs.

While our results are substantial because of the quality and variety of our risk measures, the size and representativeness of our sample and the amount of controls that we have gathered, there is still one important issue that cannot be adequately resolved by our study and will need to be addressed in future research. We have been able to establish correlations 
between various measures of behavior in risky situations and a number of outcome variables, but we cannot, with this sample, confidently determine the direction of causality. Do preferences cause well-being as is assumed by much of the existing theoretical literature or do the preferences of people change with their economic circumstances? To untangle these relationships will require econometric instruments that can be used to predict preferences but are only correlated with outcomes because of their causal effect on preferences. Clearly, this will be a "hard nut to crack" and more work will be required to develop convincing instruments.

\section{References}

Adubi, A., 1996. Impact of socio-economic factors on risk behavior of small farmers: An empirical evidence from Oyo north agricultural development project, Nigeria. African Development Review. 8(1), 115-126.

Angeletos, G.-M., Laibson, D., Repetto, A., Tobacman, J. and Weinberg, S., 2001. The hyperbolic consumption model: Calibration, simulation and empirical evaluation. Journal of Economic Perspectives. 13(3), 47-68.

Arrow, K., 1965. Aspects of the theory of risk bearing. Yrjo Jahnssonin Saatio, Helsinki.

Ashraf, N., Karlan, D. and Yin, W., 2006. Tying odysseus to the mast: Evidence from a commitment savings product in the Philippines. Quarterly Journal of Economics. 121(2), 635-672.

Azariadis, C., Stachurski, J., Philippe, A. and Steven, N.D., 2005. Chapter 5 poverty traps, Handbook of economic growth, Elsevier, pp. 295-384.

Banerjee, A., 2000. The two poverties, MIT Department of Economics Working Paper 01-16, Cambridge.

Barr, A. and Genicot, G., 2008. Risk pooling, commitment, and information: An experimental analysis. Journal of the European Economic Association. 6(6), 1151-1185.

Bertrand, M. and Mullainathan, S., 2001. Do people mean what they say? Implications for subjective survey data. American Economic Review. 91(2), 67-72.

Binswanger, H., 1980. Attitudes toward risk: Experimental measurement in rural India. American Journal of Agricultural Economics. 62(August), 395-407.

Bosch-Domenech, A. and Silvestre, J., 2006. Do the wealthy risk more money? An experimental comparison, In: C. Aliprantis and N. Yannelis (Eds.), Institutions, equilibria and efficiency, Springer, Berlin, pp. 95-115.

Calonico, S., Candelo, N., Cardenas, J.C., Chong, A., Nopo, H. et al., 2007. To what extent do latin americans trust and cooperate? Field experiments on social exclusion in six Latin American countries, In: G. Marquez, A. Chong, S. Duryea, J. Mazza and H. Nopo (Eds.), Outsiders? The changing patterns of exclusion in Latin America and the Caribbean, Inter-American Development Bank, Washington D.C., pp. 123-148.

Donkers, B., Melenberg, B. and Van Soest, A., 2001. Estimating risk attitudes using lotteries: A large sample approach. Journal of Risk and Uncertainty. 22(2), 165-195.

Eckel, C., Johnson, C. and Montmarquette, C., 2005. Saving decisions of the working poor: Short- and long-term horizons, In: J. Carpenter, G. Harrison and J. List (Eds.), Field experiments in economics, JAI/Elsevier, Amsterdam, pp. 219-260.

Ellsberg, D., 1961. Risk, ambiguity, and the savage axioms. Quarterly Journal of Economics. 75(4), 643-669.

Engle-Warnick, J., Escobal, J. and Laszlo, S., 2008. Ambiguity aversion and portfolio choice in small-scale Peruvian farming, Department of Economics, McGill University Working Paper. 
Fisher, I., 1930. The theory of interest. Macmillan, New York.

Halek, M. and Eisenhauer, J., 2001. Demography of risk aversion. The Journal of Risk and Insurance. 68(1), 1-24.

Harrison, G.W., Lau, M.I. and Williams, M.B., 2002. Estimating individual discount rates in Denmark: A field experiment. American Economic Review. 92(5), 1606-1617.

Hartog, J., Ferrer-i-Carbonell, A. and Jonker, N., 2002. Linking measured risk aversion to individual characteristics. Kyklos. 55, 3-26.

Henrich, J., Boyd, R., Bowles, S., Camerer, C., Fehr, E. et al., 2001. In search of homo economics: Behavioral experiments in 15 small-scale societies. American Economic Review. 91(2), 73-78.

Henrich, J. and McElreath, R., 2002. Are peasants risk-averse decision makers? Current Anthropology. 43(1), 172-181.

Henrich, J., McElreath, R., Barr, A., Ensminger, J., Barrett, C. et al., 2006. Costly punishment across human societies. Science. 312(23 June 2006), 1767-1770.

Herrman B., Thoeni, C., and Gachter S., 2008. Antisocial punishment across societies. Science. 319(5868), 1362-1367.

Holden, S., Shiferraw, B. and Wik, M., 1998. Poverty, market imperfections and time preferences: Of relevance for environmental policy? Environment and Development Economics. 3, 105-130.

Holt, C. and Laury, S., 2002. Risk aversion and incentive effects. American Economic Review. 92(5), 1644-1655.

Holzmann, R. and Jorgensen, S., 1999. Social protection as social risk management: Conceptual underpinnings for the social protection sector strategy paper. Journal of International Development. 11, 1005-1027.

Kagel, J., Battalio, R. and Green, 1995. Intertemporal choice, In: J. Kagel (Ed.), Economic choice theory: An experimental analysis of animal behavior, Cambridge University Press, New York, pp. 173-199.

Kahneman, D., Slovic, P. and Tversky, A., 1982. Judgment under uncertainty: Heuristics and biases. Cambridge University Press, Cambridge.

Kahneman, D. and Tversky, A., 1979. Prospect theory: An analysis of choice under risk. Econometrica. 47, 263-291.

Katz, E. and Stark, O., 1986. Labor migration and risk aversion in less developed countries. Journal of Labor Economics. 4(1), 134-149.

Klibanoff, P., Marinacci, M. and Mukerji, S., 2005. A smooth model of decision-making under ambiguity. Econometrica. 73(6), 1849-1892.

Knight, J., Weir, S. and Woldehanna, T., 2003. The role of education in facilitating risk-taking and innovation in agriculture. Journal of Development Studies. 39(6), 1-22.

Lawrance, E., 1991. Poverty and the rate of time preference: Evidence from panel data. Journal of Political Economy. 99(1), 54-77.

Lipton, M., 1968. The theory of the optimizing peasant. Journal of Development Studies. $4(3), 327-351$.

Lybbert, T. and Just, D., 2007. Is risk aversion really correlated with wealth? How estimated probabilities introduce spurious correlation. American Journal of Agricultural Economics. 89(4), 964-979.

Moscardi, E. and de Janvry, A., 1977. Attitudes toward risk among peasants: An econometric approach. American Journal of Agricultural Economics. 59(4), 710-716.

Netting, R., 1993. Smallholders, householders: Farm families and the ecology of intensive, sustainable agriculture. Stanford University Press, Stanford.

Ogaki, M. and Atkeson, A., 1997. Rate of time preference, intertemporal elasticity of substitution, and level of wealth. Review of Economics and Statistics. 79(4), 564-572.

Pender, J.L., 1996. Discount rates and credit markets: Theory and evidence from rural India. Journal of Development Economics. 50(2), 257-296.

Pratt, J., 1964. Risk aversion in the small and in the large. Econometrica. 32, 122-136. 
Rosenzweig, M. and Wolpin, K., 1993. Credit market constraints, consumption smoothing, and the accumulation of durable production assets in low-income countries: Investments in bullocks in India. Journal of Political Economy. 101(2), 223-244.

Sillers, D., 1980. Measuring risk preferences of rice farmers in Nueva Ecija, Phillippines: An experimental approach, Ph.D. thesis, Yale, New Haven.

Sinha, S. and Lipton, M., 1999. Damaging fluctuations, risk and poverty: A review, Background Paper for the World Development Report 2000/2001.

Stiglitz, J., 1989. Markets, market failures, and development. American Economic Review. 79(2), 197-203.

Thaler, R., 1997. Irving fisher: Modern behavioral economist. American Economic Review. 87(2), 439-441.

Tversky, A. and Kahneman, D., 1981. The framing of decisions and the psychology of choice. Science. 211, 453-458.

Walker, T., 1980. Decision making by farmers and by the national agricultural research program on the adoption and development of maize varieties in El Salvador, Ph.D. thesis Stanford, Palo Alto.

Yesuf, M. and Bluffstone, R., 2007. Risk aversion in low income countries, IFPRI Discussion Paper 00715. 


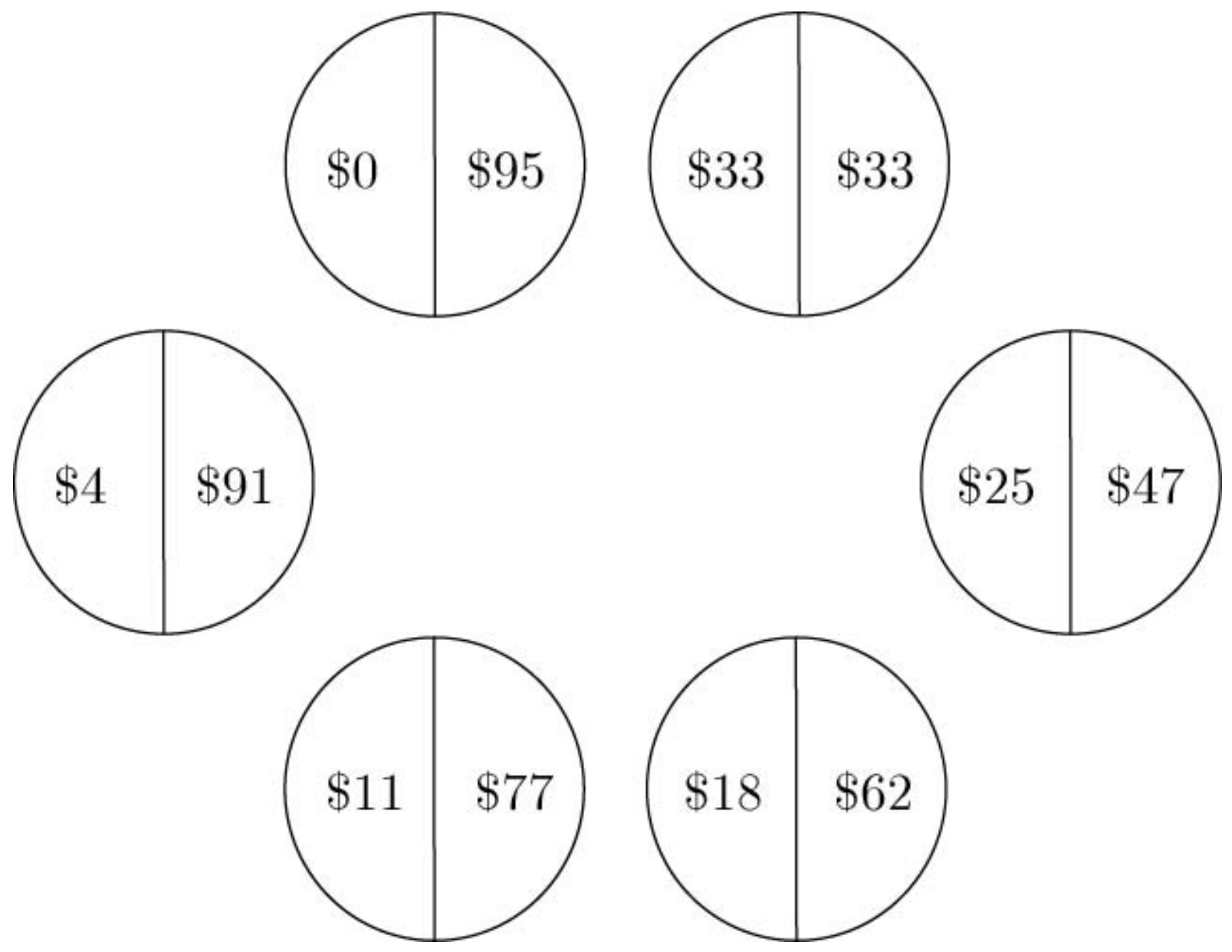

Figure 1. The decision task (with representative U.S. dollar payoffs) used to assess attitudes towards risk. Participants are asked to choose one of six 50-50 lotteries in which the odds of a high payment are the same as the odds of a low payment. As one moves clock-wise around the ring, the lotteries increase in risk and expected payoff except for the last lottery which has the same expected payoff as the fifth but is riskier. The participant's risk attitude can be bound by the chosen lottery. To determine payoffs for the task, the experimenter uses a bag of five low value balls and five high value balls where the ball values are determined by the chosen lottery and the participant blindly picks a ball from the bag. 


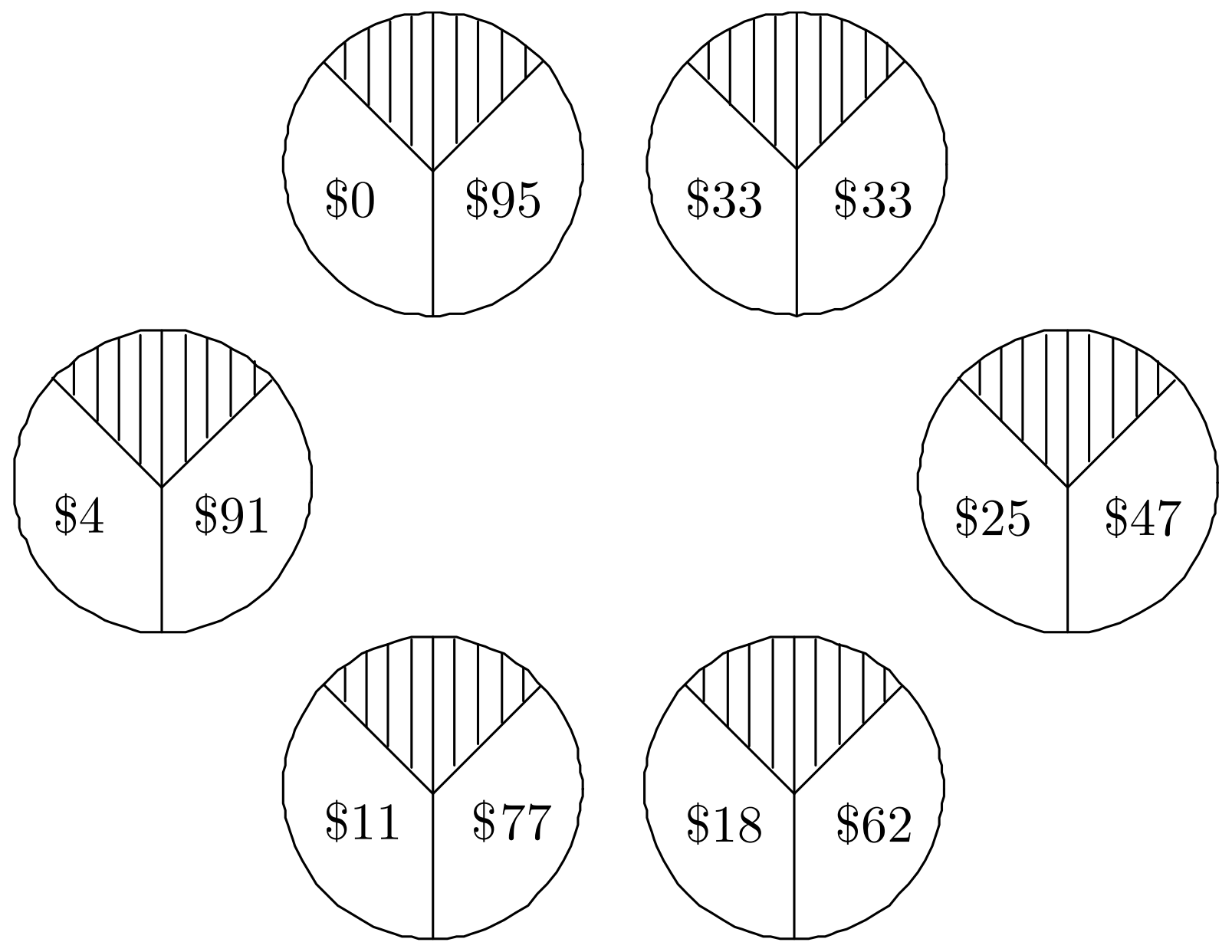

Figure 2. The decision task (with representative U.S. dollar payoffs) used to assess attitudes towards ambiguity. Participants were asked to choose one of six lotteries in which the odds of a high or low payment are bound between $3 / 10$ and $7 / 10$ but are unknown. 


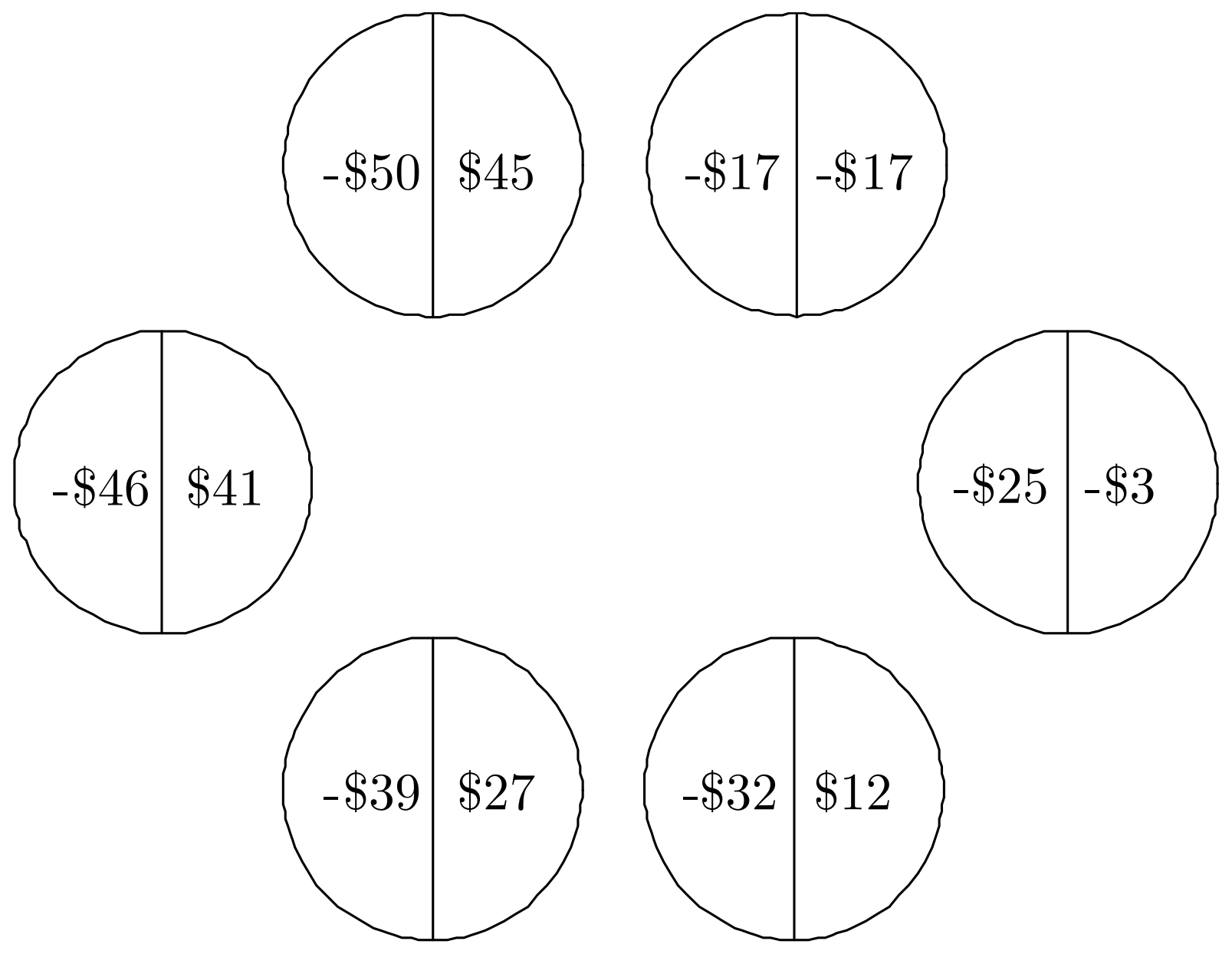

Figure 3: The decision task (with representative U.S. dollar payoffs) used to assess attitudes towards losses. Participants were asked to choose one of six lotteries in which the odds of a high or low payment are equalized but some payoffs are negative. However, the only difference in this task and the risky task in Figure 1 is the frame; if one adds the $\$ 50$ endowment for this task to all the payoffs, one is back to the decision depicted in Figure 1. 


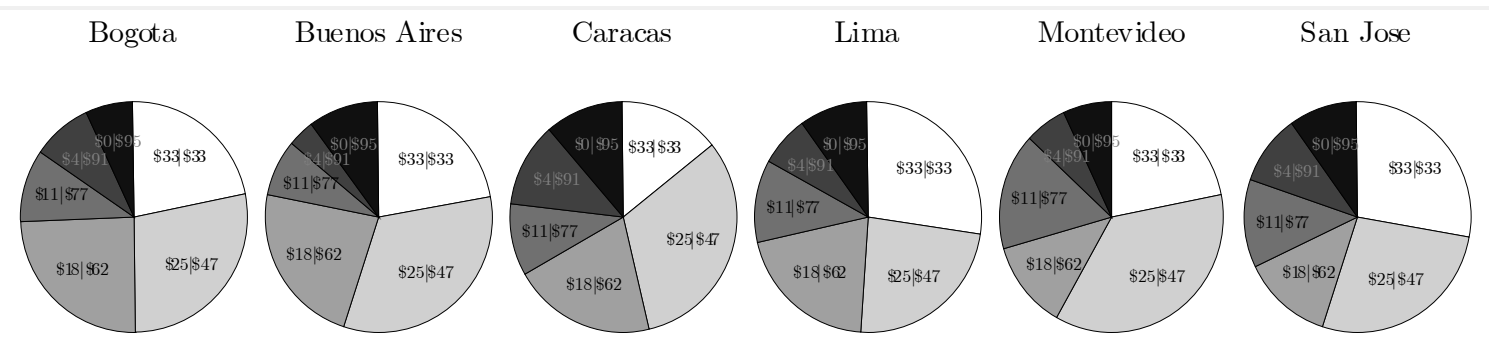

Panel (a): Risk Choices.

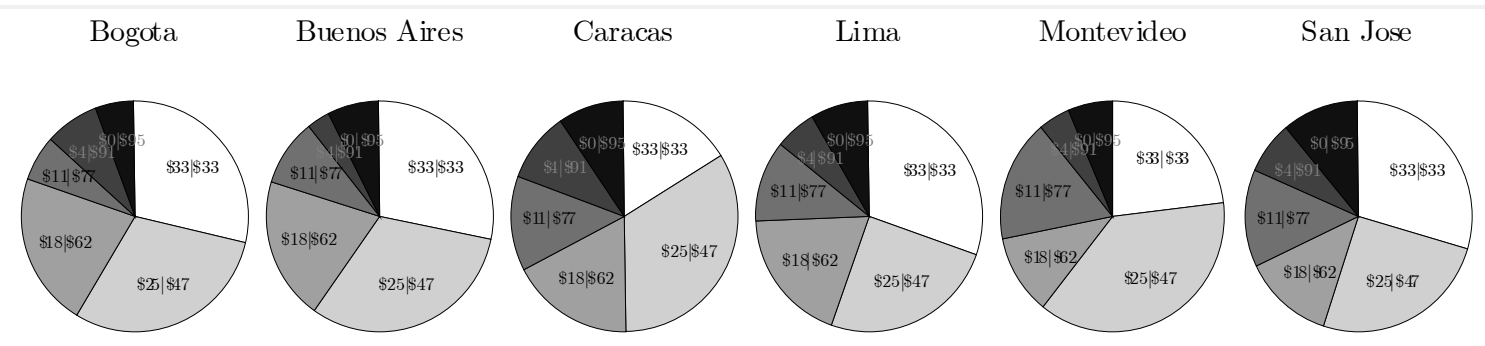

Panel (b): Ambiguous Choices.

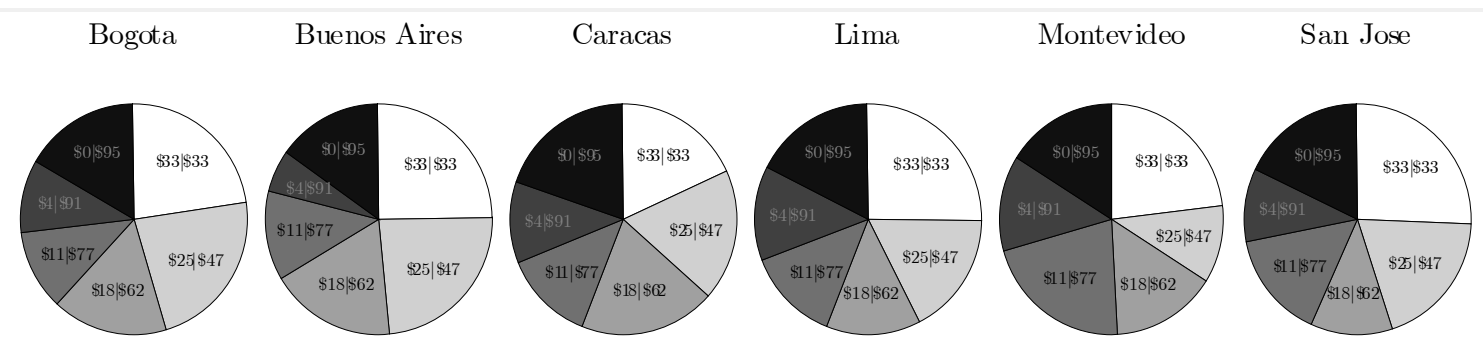

Panel (c): Choices with Losses.

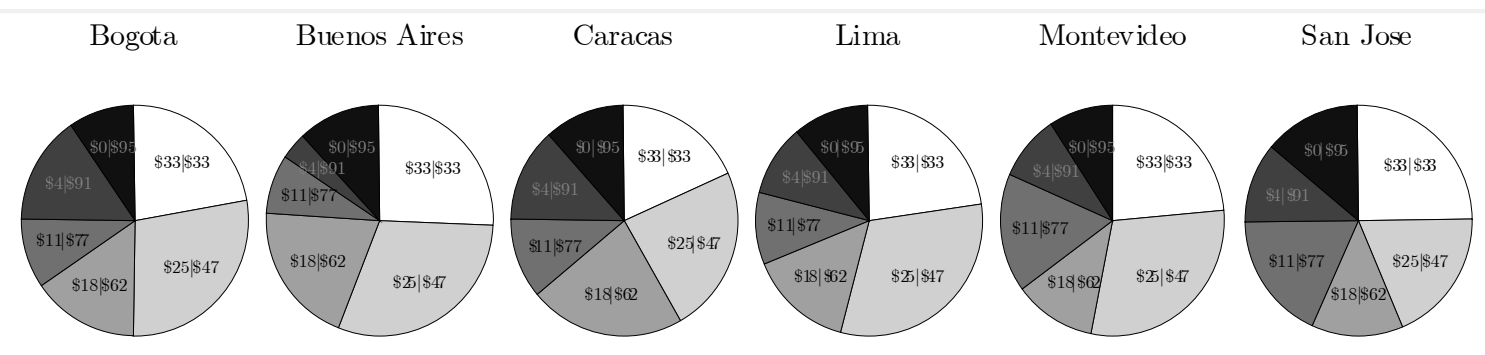

Panel (d): Pooler Choices.

Figure 4. The distribution of lottery choices by location and treatment. 


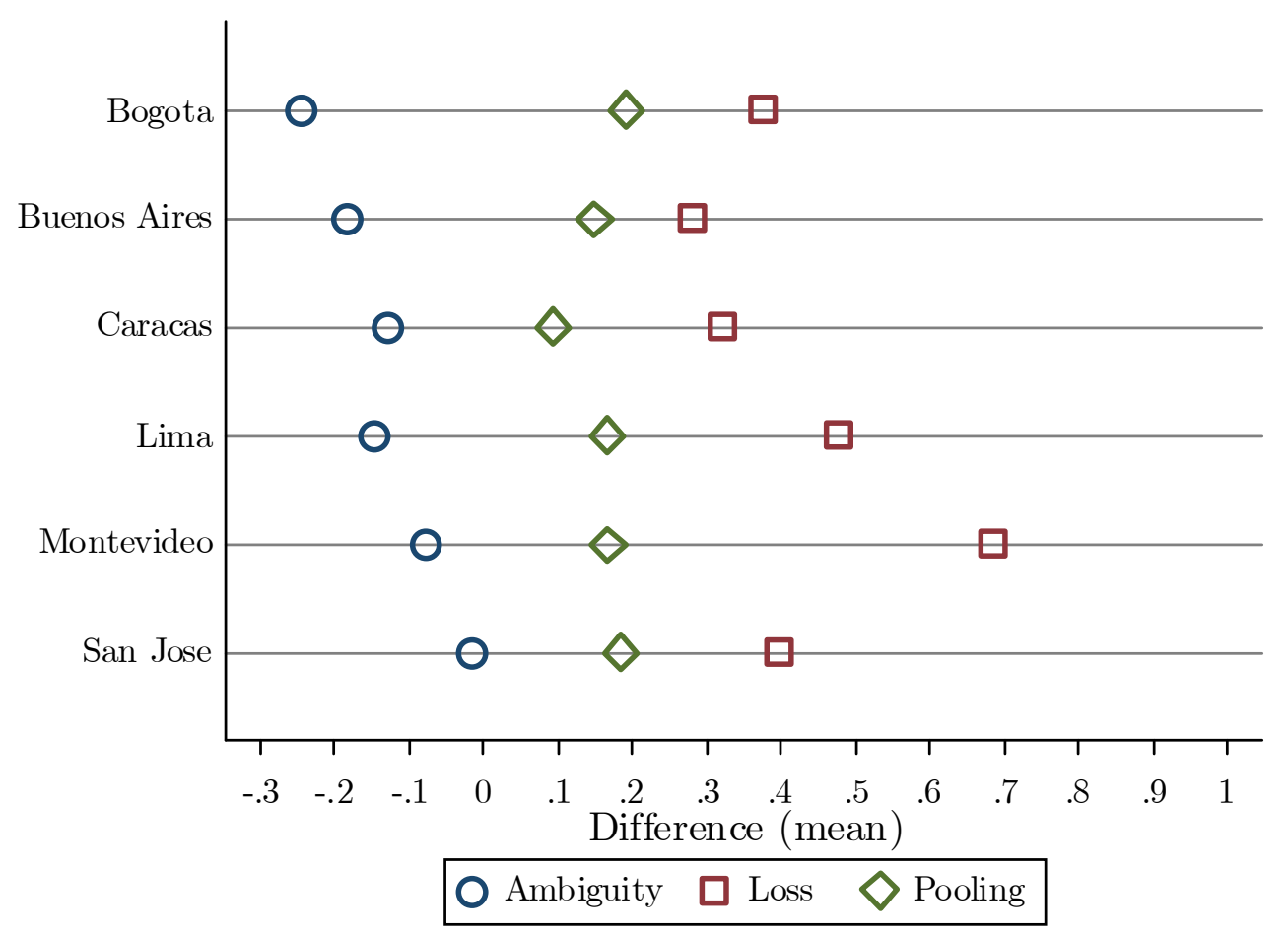

Figure 5. City level differences in treatment responses. Circles represent the city-level mean difference in ambiguous lottery choice from the risky baseline. Squares represent mean differences when losses are possible and diamonds represent mean differences of poolers when risk could be pooled. The figure groups the data by city. 

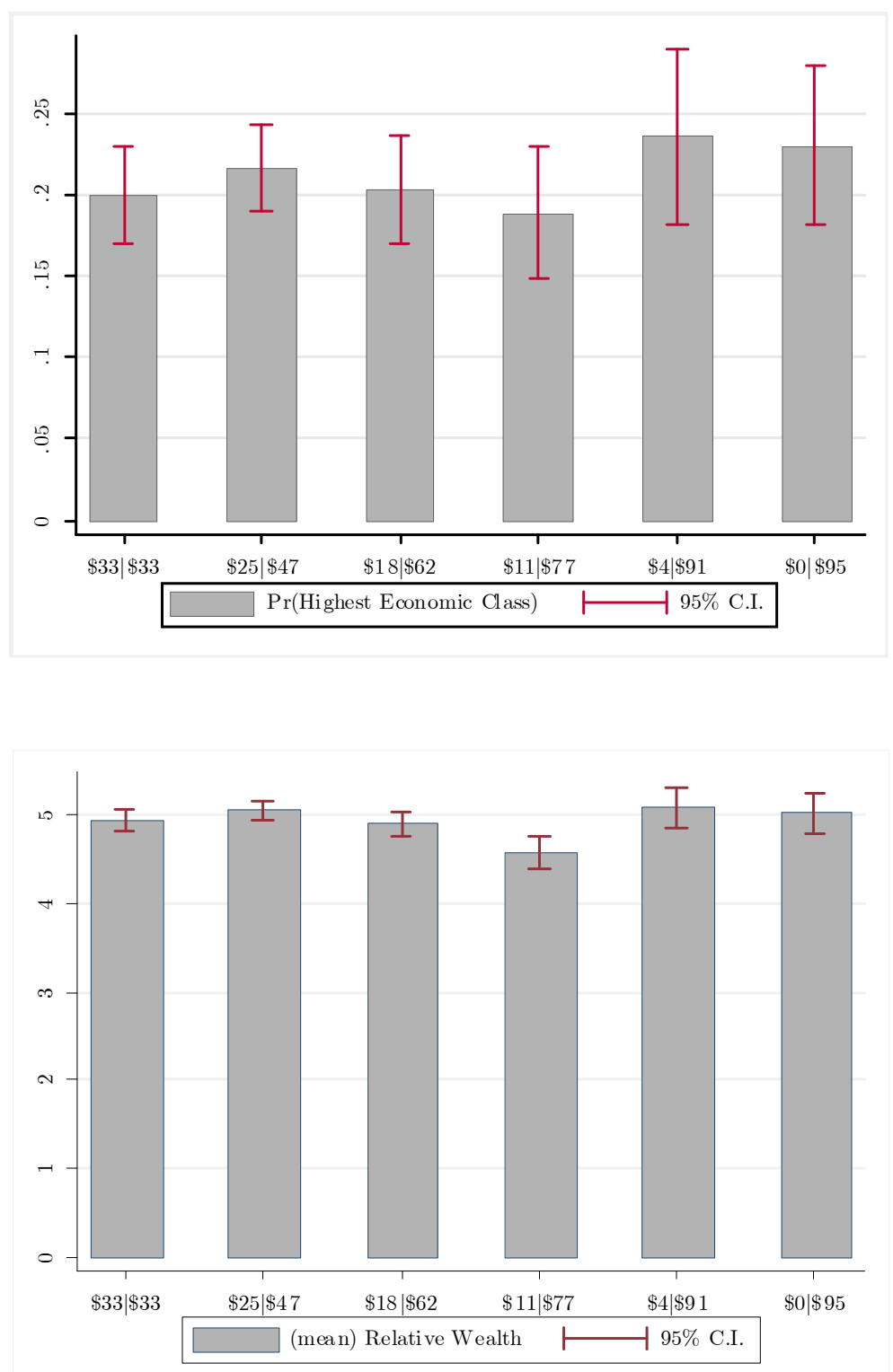

Figure 6. Simple measures of risk tolerance and well-being. Both panels represent the relationship between lottery choices and well-being. In the upper panel well-being is measured by the objective criteria of neighborhood wealth (probability of being in the top of three classes). In the lower panel well-being is measured by participant subjective evaluations of their relative wealth compared to others in their city (on a scale from 1 to 10). 

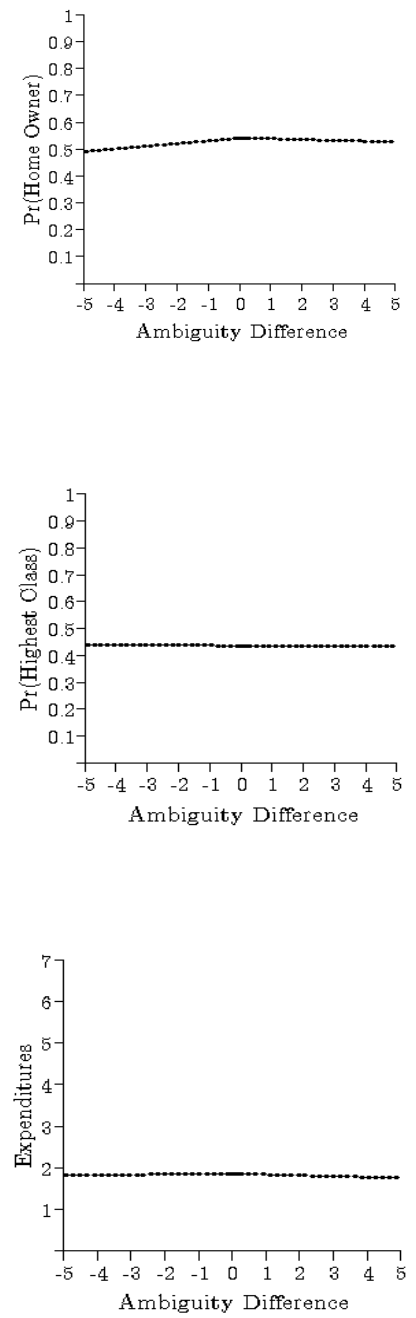
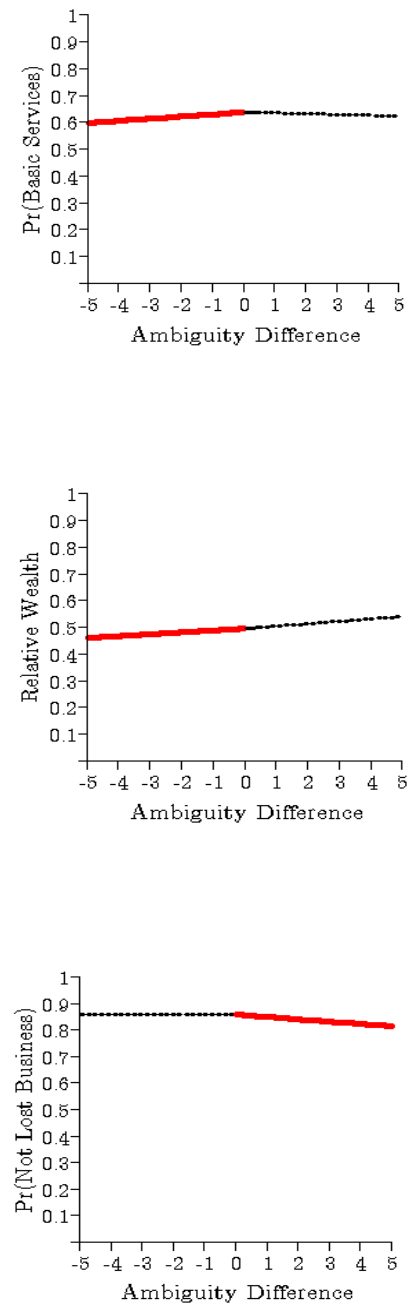
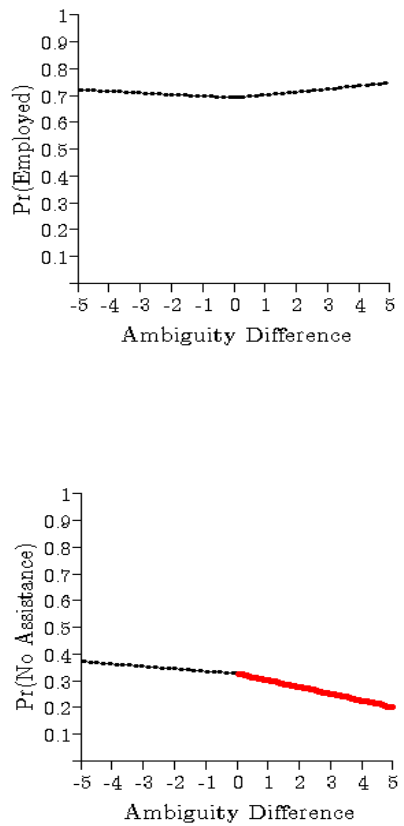

Figure 7. Well-Being and Ambiguity. Each panel graphs the estimated relationship between individual reactions to ambiguity and the eight dimensions of well-being. Solid red lines indicate sides of the spline that are significant at the $10 \%$ level or better. Each specification controls for pooling in the shared risk task, gender, age, college, married, ethnicity, home size, children, income earners, access to credit and access to the political process. 

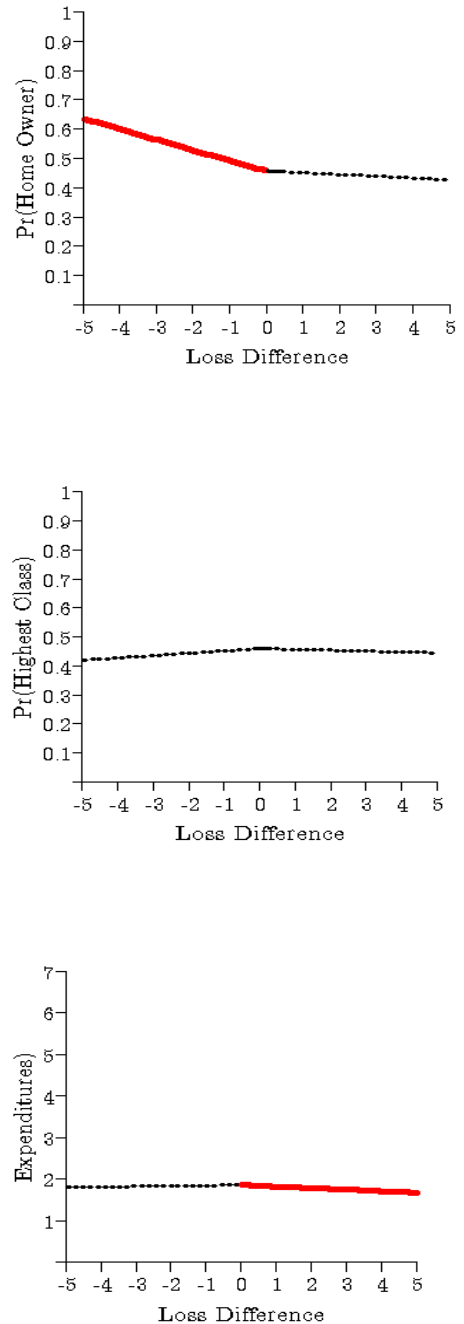
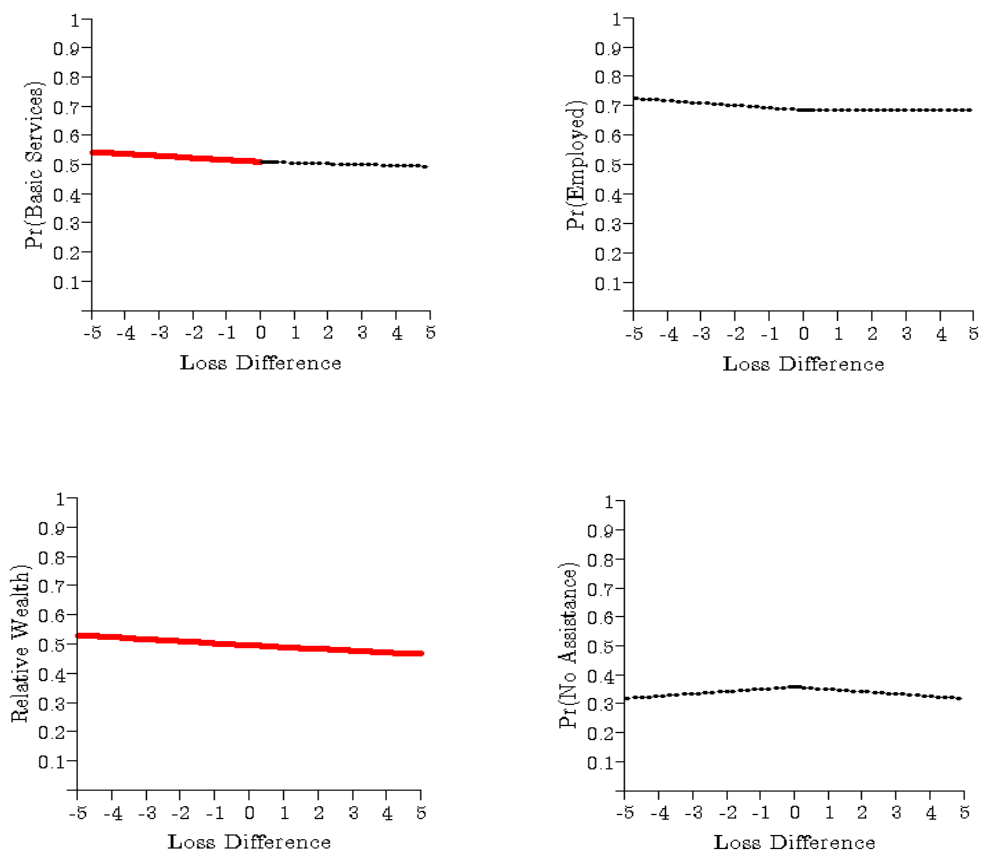

Figure 8. Well-Being and Losses. Each panel

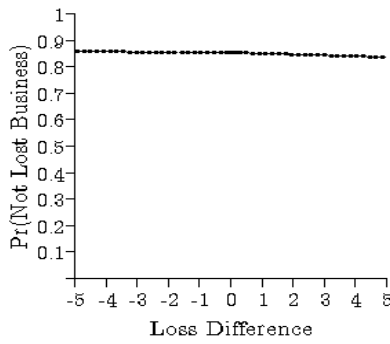
indi vidual reactions to potential losses and the eight dimensions of well-being. Solid red lines indicate sides of the spline that are significant at the $10 \%$ level or better. Each specification controls for pooling in the shared risk task, gender, age, college, married, ethnicity, home size, children, income earners, access to credit and access to the political process. 

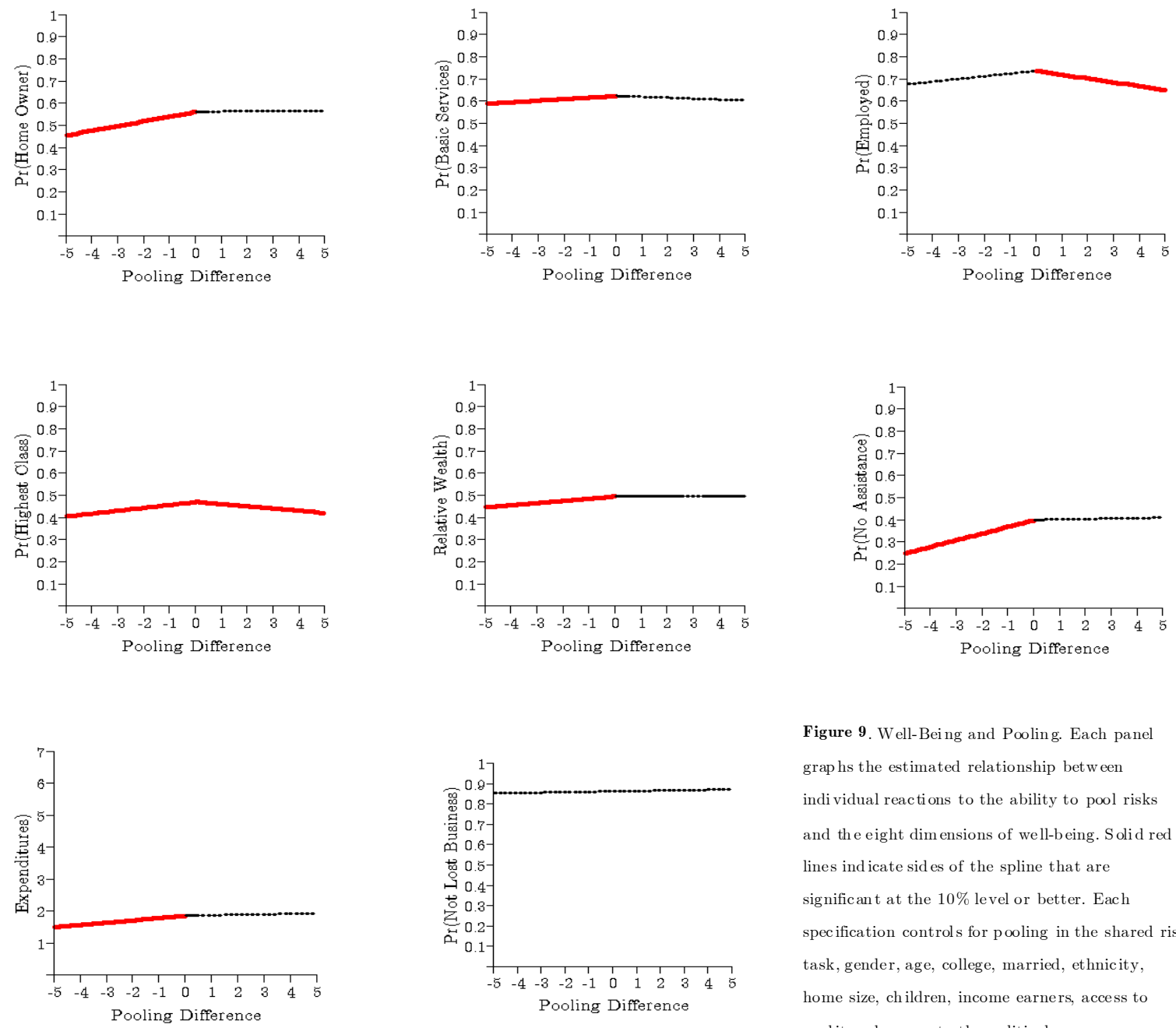

Figure 9. Well-Being and Pooling. Each panel graphs the estimated relationship between individual reactions to the ability to pool risks and the eight dimensions of well-being. Solid red lines ind icate sides of the spline that are significant at the $10 \%$ level or better. Each specification controls for pooling in the shared risk task, gender, age, college, married, ethnicity, home size, children, income earners, access to cred it and access to the political process. 


\begin{tabular}{|c|c|c|c|c|c|c|c|c|}
\hline & & Bogotá & Buenos Aires & Caracas & Lima & Montevideo & San José & Overall \\
\hline \multicolumn{9}{|l|}{ Socio-economic Class } \\
\hline & $\%$ low & 42 & 33 & 21 & 15 & 19 & 26 & 26 \\
\hline & $\%$ mid & 44 & 34 & 54 & 75 & 56 & 53 & 53 \\
\hline & $\%$ high & 14 & 33 & 25 & 10 & 25 & 21 & 21 \\
\hline Female (indicator) & & $0.58(0.49)$ & $0.51(0.50)$ & $0.55(0.50)$ & $0.52(0.50)$ & $0.56(0.50)$ & $0.61(0.49)$ & $0.56(0.50)$ \\
\hline Age (years) & & $36.50(13.29)$ & $39.64(15.20)$ & $33.66(12.54)$ & $34.82(12.87)$ & 41.31 (15.99) & $37.25(15.88)$ & $37.27(14.58)$ \\
\hline College (indicator) & & $0.01(0.10)$ & $0.01(0.10)$ & $0.05(0.21)$ & $0.02(0.13)$ & $0.01(0.04)$ & $0.03(0.18)$ & $0.02(0.14)$ \\
\hline Married (indicator) & & $0.24(0.43)$ & $0.41(0.49)$ & $0.27(0.44)$ & $0.28(0.45)$ & $0.33(0.47)$ & $0.32(0.47)$ & $0.31(0.46)$ \\
\hline Children (number) & & $1.27(1.17)$ & $0.86(1.17)$ & $1.11(1.21)$ & $1.28(1.33)$ & $0.78(1.00)$ & $1.35(1.36)$ & $1.10(1.22)$ \\
\hline Indigenous Heritage (indicator) & & $0.02(0.14)$ & $0.02(0.14)$ & $0.01(0.11)$ & $0.01(0.12)$ & $0.02(0.14)$ & $0.03(0.16)$ & $0.02(0.14)$ \\
\hline Black Heritage (indicator) & & $0.01(0.11)$ & $0.01(0.08)$ & $0.05(0.22)$ & $0.01(0.12)$ & $0.04(0.20)$ & $0.04(0.19)$ & $0.03(0.16)$ \\
\hline Home Size (bedrooms) & & $2.66(1.03)$ & $2.28(0.96)$ & $3.06(1.20)$ & $2.64(1.34)$ & $2.25(0.90)$ & $2.93(1.38)$ & $2.62(1.18)$ \\
\hline Income Earners (number) & & $1.91(1.05)$ & $2.01(0.99)$ & $2.30(1.11)$ & $2.18(1.24)$ & $2.00(0.97)$ & $1.94(1.17)$ & $2.06(1.10)$ \\
\hline No Access Credit (indicator) & & $0.32(0.47)$ & $0.17(0.37)$ & $0.35(0.48)$ & $0.26(0.44)$ & $0.10(0.30)$ & $0.21(0.41)$ & $0.23(0.42)$ \\
\hline № Access Politics (indicator) & & $0.06(0.23)$ & $0.01(0.11)$ & $0.03(0.17)$ & $0.05(0.22)$ & $0.02(0.14)$ & $0.07(0.25)$ & $0.04(0.19)$ \\
\hline N (participants) & & 567 & 498 & 488 & 541 & 580 & 435 & 3109 \\
\hline Sessions & & 31 & 25 & 25 & 28 & 28 & 22 & 159 \\
\hline Mean Session Size & & 21 & 20 & 20 & 23 & 22 & 26 & 22 \\
\hline
\end{tabular}

Table 1. Summary statistics of participant characteristics by city (standard deviation). 


\begin{tabular}{r|cccccc} 
& $\$ 33 \mid \$ 33$ & $\$ 25 \mid \$ 47$ & $\$ 18 \mid \$ 62$ & $\$ 11 \mid \$ 77$ & $\$ 4 \mid \$ 91$ & $\$ 0 \mid \$ 95$ \\
\hline$\$ 33 \mid \$ 33$ & - & HO & EM, EC & RW & \\
$\$ 25 \mid \$ 47$ & NRA & - & EM, EC & RW & BS & \\
$\$ 18 \mid \$ 62$ & & & - & RW & NLB \\
$\$ 11 \mid \$ 77$ & & & - & NLB & \\
$\$ 4 \mid \$ 91$ & & EC & EC, RW & - & - \\
$\$ 0 \mid \$ 95$ & & EM & RW & NLB
\end{tabular}

Table 2. Does well-being increase with risk tolerance? The different lotteries are represented on the columns and rows. All entries indicate that the row lottery has a significantly larger coefficient at the $10 \%$ level than the column lottery. The shaded entries below the diagonal therefore suggest that being more tolerant of risk is associated with higher well-being in the relevant domain. Entries above the diagonal indicate that being less tolerant of risk (i.e., more risk aversion) is associated with higher well-being. The coefficients come from regressions that control for gender, age, college education, married, ethnicity, home size, number of children, number of income earners, access to credit and access to the political process. The key for the well-being domains is: $\mathrm{HO}=$ Home ownership, $\mathrm{BS}=$ Basic services, EM $=$ Employed, $\mathrm{EC}=$ Economic class, $\mathrm{RW}=$ Relative wealth, NRA $=$ Not require assistance, $\mathrm{EX}=$ Expenditures and NLB $=$ Never lost a business. 


\begin{tabular}{|c|c|c|c|c|c|c|c|c|}
\hline & $\begin{array}{c}\text { Home } \\
\text { Ownership } \\
\text { [indicator] }\end{array}$ & $\begin{array}{c}\text { Basic } \\
\text { Services } \\
{[\operatorname{Pr}(\text { all } 3)]}\end{array}$ & $\begin{array}{c}\text { Employment } \\
\text { [indicator] }\end{array}$ & $\begin{array}{c}\text { Economic } \\
\text { C lass } \\
{[\operatorname{Pr}(\text { high })]}\end{array}$ & $\begin{array}{c}\text { Relative } \\
\text { W ealth } \\
\text { [unit interval] }\end{array}$ & $\begin{array}{l}\text { Not Require } \\
\text { Assistance } \\
\text { [ind icator] }\end{array}$ & $\begin{array}{l}\text { Expenditures } \\
\text { [\# min wages] }\end{array}$ & $\begin{array}{l}\text { Not Lost } \\
\text { a Busin ess } \\
\text { [ind icator] }\end{array}$ \\
\hline Accept Less Risk under Ambiguity & $\begin{array}{l}0.010 \\
(0.011)\end{array}$ & $\begin{array}{l}0.040^{\text {** }} \\
(0.017)\end{array}$ & $\begin{array}{l}-0.008 \\
(0.014)\end{array}$ & $\begin{array}{l}-0.001 \\
(0.010)\end{array}$ & $\begin{array}{l}0.069^{*} \\
(0.038)\end{array}$ & $\begin{array}{l}-0.009 \\
(0.012)\end{array}$ & $\begin{array}{l}0.009 \\
(0.031)\end{array}$ & $\begin{array}{l}0.001 \\
(0.011)\end{array}$ \\
\hline Accept More Risk under Am bigu ity & $\begin{array}{l}-0.003 \\
(0.012)\end{array}$ & $\begin{array}{l}-0.012 \\
(0.018)\end{array}$ & $\begin{array}{l}0.016 \\
(0.014)\end{array}$ & $\begin{array}{l}-0.001 \\
(0.011)\end{array}$ & $\begin{array}{l}0.045 \\
(0.046)\end{array}$ & $\begin{array}{l}-0.025^{*} \\
(0.013)\end{array}$ & $\begin{array}{l}-0.021 \\
(0.029)\end{array}$ & $\begin{array}{l}-0.020^{* *} \\
(0.010)\end{array}$ \\
\hline Accept Less Risk with Losses & $\begin{array}{l}-0.037^{\text {*** }} \\
(0.012)\end{array}$ & $\begin{array}{l}-0.032^{* *} \\
(0.016)\end{array}$ & $\begin{array}{l}-0.011 \\
(0.015)\end{array}$ & $\begin{array}{l}0.012 \\
(0.011)\end{array}$ & $\begin{array}{l}-0.072^{* *} \\
(0.035)\end{array}$ & $\begin{array}{l}0.008 \\
(0.013)\end{array}$ & $\begin{array}{l}0.011 \\
(0.032)\end{array}$ & $\begin{array}{l}-0.001 \\
(0.010)\end{array}$ \\
\hline Accept More Risk with Losses & $\begin{array}{l}-0.006 \\
(0.007)\end{array}$ & $\begin{array}{l}-0.013 \\
(0.013)\end{array}$ & $\begin{array}{l}0.001 \\
(0.009)\end{array}$ & $\begin{array}{l}-0.003 \\
(0.008)\end{array}$ & $\begin{array}{l}-0.063^{* *} \\
(0.026)\end{array}$ & $\begin{array}{l}-0.008 \\
(0.010)\end{array}$ & $\begin{array}{c}-0.036^{*} \\
(0.022)\end{array}$ & $\begin{array}{l}-0.008 \\
(0.008)\end{array}$ \\
\hline Accept Less Risk in Group & $\begin{array}{l}0.021^{*} \\
(0.012)\end{array}$ & $\begin{array}{l}0.032^{*} \\
(0.018)\end{array}$ & $\begin{array}{l}0.017 \\
(0.015)\end{array}$ & $\begin{array}{l}0.018^{*} \\
(0.010)\end{array}$ & $\begin{array}{l}0.104^{* * *} \\
(0.036)\end{array}$ & $\begin{array}{c}0.030^{* *} \\
(0.013)\end{array}$ & $\begin{array}{l}0.072^{* *} \\
(0.032)\end{array}$ & $\begin{array}{l}0.003 \\
(0.010)\end{array}$ \\
\hline Accept More Risk in Group & $\begin{array}{l}0.001 \\
(0.010)\end{array}$ & $\begin{array}{l}-0.022 \\
(0.016)\end{array}$ & $\begin{array}{c}-0.025^{* *} \\
(0.013)\end{array}$ & $\begin{array}{l}-0.014^{*} \\
(0.009)\end{array}$ & $\begin{array}{l}0.007 \\
(0.034)\end{array}$ & $\begin{array}{l}0.002 \\
(0.012)\end{array}$ & $\begin{array}{l}0.014 \\
(0.025)\end{array}$ & $\begin{array}{l}0.003 \\
(0.008)\end{array}$ \\
\hline No Access to Credit & $\begin{array}{l}-0.054^{* * *} \\
(0.022)\end{array}$ & $\begin{array}{l}-0.008 \\
(0.009)\end{array}$ & $\begin{array}{l}-0.013 \\
(0.018)\end{array}$ & $\begin{array}{l}-0.049^{* * *} \\
(0.015)\end{array}$ & $\begin{array}{l}-0.349^{* * *} \\
(0.071)\end{array}$ & $\begin{array}{l}-0.059^{* *} \\
(0.026)\end{array}$ & $\begin{array}{l}-0.309^{\text {*** }} \\
(0.067)\end{array}$ & $\begin{array}{l}-0.050^{* * *} \\
(0.012)\end{array}$ \\
\hline No Access to Politics & $\begin{array}{l}-0.008 \\
(0.051)\end{array}$ & $\begin{array}{l}-0.038^{*} \\
(0.021)\end{array}$ & $\begin{array}{l}-0.063 \\
(0.044)\end{array}$ & $\begin{array}{l}-0.014 \\
(0.028)\end{array}$ & $\begin{array}{l}-0.056 \\
(0.154)\end{array}$ & $\begin{array}{l}-0.145^{* *} \\
(0.062)\end{array}$ & $\begin{array}{l}0.018 \\
(0.119)\end{array}$ & $\begin{array}{l}-0.017 \\
(0.021)\end{array}$ \\
\hline$\overline{\mathrm{R}^{2} \text { or pseudo } \mathrm{R}^{2}}$ & 0.07 & 0.11 & 0.07 & 0.05 & 0.04 & 0.06 & 0.04 & 0.05 \\
\hline p-value from $\mathrm{Chi}^{2}$ or $\mathrm{F}$ test & $<0.01$ & $<0.01$ & $<0.01$ & $<0.01$ & $<0.01$ & $<0.01$ & $<0.01$ & $<0.01$ \\
\hline Observations & 3087 & 3087 & 2169 & 3082 & 3086 & 2418 & 2810 & 3087 \\
\hline
\end{tabular}

Table 3. Risk attitudes and well-being. Each column refers to a different aspect of wellbeing. The regressions are splines to allow reactions to differ depending on whether or not one reacts more or less conservatively to the treatments. The splines are estimated with either OLS, Probit, Ordered Probit or Tobit depending on the restrictions on the dependent variable. The standard errors (in parentheses) are clustered at the session level. Marginal effects are reported instead of coefficients. The specification for each characteristic includes controls for pooling in the shared risk task, gender, age, college education, married, ethnicity, home size, number of children, number of income earners, access to credit and access to the political process. $* * *, * *, *$ indicate significant at the $1 \%, 5 \%$ and $10 \%$ levels. 


\begin{tabular}{|c|c|c|c|c|}
\hline & Risk Choice & Ambiguous Choice & Loss Choice & Pooling Choice \\
\hline \multirow[t]{2}{*}{ Buenos Aires } & 0.011 & -0.005 & 0.034 & 0.034 \\
\hline & $(0.022)$ & $(0.024)$ & $(0.023)$ & $(0.031)$ \\
\hline \multirow[t]{2}{*}{ Caracas } & $-0.062^{* * *}$ & $-0.099^{* * *}$ & $-0.050^{* *}$ & -0.032 \\
\hline & $(0.019)$ & $(0.020)$ & $(0.025)$ & $(0.028)$ \\
\hline \multirow[t]{2}{*}{ Lima } & 0.004 & -0.022 & -0.015 & 0.012 \\
\hline & $(0.023)$ & $(0.026)$ & $(0.024)$ & $(0.029)$ \\
\hline \multirow[t]{2}{*}{ Montevideo } & 0.015 & -0.031 & -0.022 & 0.007 \\
\hline & $(0.020)$ & $(0.020)$ & $(0.021)$ & $(0.030)$ \\
\hline \multirow[t]{2}{*}{ San Jose } & 0.010 & $-0.049^{*}$ & -0.007 & -0.029 \\
\hline & $(0.031)$ & $(0.029)$ & $(0.027)$ & $(0.036)$ \\
\hline \multirow[t]{2}{*}{ Female } & $0.034^{* * *}$ & $0.056^{* * *}$ & $0.059^{* * *}$ & $0.047^{* * *}$ \\
\hline & $(0.012)$ & $(0.013)$ & $(0.011)$ & $(0.018)$ \\
\hline \multirow[t]{2}{*}{ Age } & $-0.002^{* * *}$ & $-0.002^{* * *}$ & -0.003 & $-0.001^{* *}$ \\
\hline & $(0.000)$ & $(0.001)$ & $(0.001)$ & $(0.001)$ \\
\hline \multirow[t]{2}{*}{ College } & -0.021 & -0.001 & -0.019 & -0.064 \\
\hline & $(0.044)$ & $(0.053)$ & $(0.035)$ & $(0.042)$ \\
\hline \multirow[t]{2}{*}{ Married } & 0.020 & $0.037^{* *}$ & $0.048^{* * *}$ & 0.030 \\
\hline & $(0.016)$ & $(0.016)$ & $(0.016)$ & $(0.023)$ \\
\hline \multirow[t]{2}{*}{ Children } & -0.004 & -0.004 & -0.001 & 0.002 \\
\hline & $(0.005)$ & $(0.006)$ & $(0.005)$ & $(0.008)$ \\
\hline \multirow[t]{2}{*}{ Indian Her itage } & -0.021 & -0.034 & $-0.060^{*}$ & 0.004 \\
\hline & $(0.037)$ & $(0.041)$ & $(0.035)$ & $(0.067)$ \\
\hline \multirow[t]{2}{*}{ African Heritage } & -0.018 & -0.016 & -0.036 & 0.017 \\
\hline & $(0.032)$ & $(0.032)$ & $(0.039)$ & $(0.044)$ \\
\hline \multirow[t]{2}{*}{ Home Size } & -0.006 & -0.006 & 0.002 & -0.011 \\
\hline & $(0.007)$ & $(0.006)$ & $(0.006)$ & $(0.008)$ \\
\hline \multirow[t]{2}{*}{ Income Earners } & 0.003 & 0.002 & 0.001 & 0.003 \\
\hline & $(0.007)$ & $(0.007)$ & $(0.006)$ & $(0.009)$ \\
\hline \multirow[t]{2}{*}{ No Access to Credit } & -0.013 & $-0.029^{*}$ & -0.013 & $-0.049 * * *$ \\
\hline & $(0.015)$ & $(0.017)$ & $(0.014)$ & $(0.019)$ \\
\hline \multirow[t]{2}{*}{ No Access to Politics } & 0.009 & -0.037 & $0.065^{*}$ & 0.014 \\
\hline & $(0.034)$ & $(0.035)$ & $(0.037)$ & $(0.046)$ \\
\hline Observations & 3088 & 3089 & 3089 & 1482 \\
\hline Psuedo R-Squared & 0.005 & 0.008 & 0.008 & 0.006 \\
\hline
\end{tabular}

Table A1. The demographic determinants of preferences. Ordered probit results reporting probabilities of choosing the safe $\$ 33 \mid \$ 33$ lottery. Bogotá is the baseline. (Standard errors) have been clustered at the session level. *** indicates significant at the $1 \%, * * 5 \%$ and * $10 \%$ levels. 


\begin{tabular}{|c|c|c|c|}
\hline & $\begin{array}{l}\text { More Conservative } \\
\text { under Ambig uity } \\
\text { [indicator] }\end{array}$ & $\begin{array}{c}\text { Mor e Conservative } \\
\text { with Losses } \\
\text { [indicator] }\end{array}$ & $\begin{array}{c}\text { More Conservative } \\
\text { in Group } \\
\text { [indicator] }\end{array}$ \\
\hline Buenos Aires & $\begin{array}{l}-0.064^{* *} \\
(0.029)\end{array}$ & $\begin{array}{l}-0.012 \\
(0.029)\end{array}$ & $\begin{array}{l}-0.062^{* * *} \\
(0.021)\end{array}$ \\
\hline Caracas & $\begin{array}{l}-0.065^{* *} \\
(0.028)\end{array}$ & $\begin{array}{l}0.012 \\
(0.032)\end{array}$ & $\begin{array}{l}-0.065^{* * *} \\
(0.024)\end{array}$ \\
\hline Lima & $\begin{array}{l}-0.013 \\
(0.033)\end{array}$ & $\begin{array}{l}-0.017 \\
(0.026)\end{array}$ & $\begin{array}{l}0.004 \\
(0.021)\end{array}$ \\
\hline Montevideo & $\begin{array}{l}-0.067^{* *} \\
(0.029)\end{array}$ & $\begin{array}{l}-0.028 \\
(0.028)\end{array}$ & $\begin{array}{l}-0.052^{* *} \\
(0.022)\end{array}$ \\
\hline San Jose & $\begin{array}{l}-0.077^{* *} \\
(0.030)\end{array}$ & $\begin{array}{l}0.004 \\
(0.031)\end{array}$ & $\begin{array}{l}0.005 \\
(0.021)\end{array}$ \\
\hline Pool Risk & $\begin{array}{l}0.056^{* * *} \\
(0.017)\end{array}$ & $\begin{array}{l}0.020 \\
(0.017)\end{array}$ & $\begin{array}{l}0.021 \\
(0.015)\end{array}$ \\
\hline Female & $\begin{array}{l}0.039^{* * *} \\
(0.015)\end{array}$ & $\begin{array}{l}0.047^{* * *} \\
(0.018)\end{array}$ & $\begin{array}{l}0.043^{* * *} \\
(0.015)\end{array}$ \\
\hline Age & $\begin{array}{l}-0.001 \\
(0.001)\end{array}$ & $\begin{array}{l}0.001 \\
(0.001)\end{array}$ & $\begin{array}{l}0.001 \\
(0.001)\end{array}$ \\
\hline College & $\begin{array}{l}0.010 \\
(0.054)\end{array}$ & $\begin{array}{l}-0.097 \\
(0.053)\end{array}$ & $\begin{array}{l}-0.044 \\
(0.057)\end{array}$ \\
\hline Married & $\begin{array}{l}-0.017 \\
(0.019)\end{array}$ & $\begin{array}{l}0.029 \\
(0.020)\end{array}$ & $\begin{array}{l}-0.003 \\
(0.019)\end{array}$ \\
\hline Children & $\begin{array}{l}0.011 \\
(0.008)\end{array}$ & $\begin{array}{l}0.012^{*} \\
(0.007)\end{array}$ & $\begin{array}{l}0.008 \\
(0.007)\end{array}$ \\
\hline Indian Her it age & $\begin{array}{l}-0.019 \\
(0.060)\end{array}$ & $\begin{array}{l}-0.035 \\
(0.054)\end{array}$ & $\begin{array}{l}0.066 \\
(0.059)\end{array}$ \\
\hline African Heritage & $\begin{array}{l}0.043 \\
(0.050)\end{array}$ & $\begin{array}{l}-0.004 \\
(0.049)\end{array}$ & $\begin{array}{l}0.091^{*} \\
(0.057)\end{array}$ \\
\hline Home Size & $\begin{array}{l}-0.003 \\
(0.009)\end{array}$ & $\begin{array}{l}0.006 \\
(0.007)\end{array}$ & $\begin{array}{l}-0.001 \\
(0.009)\end{array}$ \\
\hline Income Earners & $\begin{array}{l}0.001 \\
(0.008)\end{array}$ & $\begin{array}{l}-0.012 \\
(0.008)\end{array}$ & $\begin{array}{l}-0.007 \\
(0.008)\end{array}$ \\
\hline No Access to Credit & $\begin{array}{l}-0.013 \\
(0.017)\end{array}$ & $\begin{array}{l}-0.004 \\
(0.020)\end{array}$ & $\begin{array}{l}-0.009 \\
(0.020)\end{array}$ \\
\hline No Access to Politics & $\begin{array}{l}-0.052 \\
(0.042)\end{array}$ & $\begin{array}{l}0.054 \\
(0.046)\end{array}$ & $\begin{array}{l}-0.007 \\
(0.041)\end{array}$ \\
\hline Observations & 3090 & 3090 & 3090 \\
\hline Psuedo R-Squared & 0.010 & 0.010 & 0.013 \\
\hline
\end{tabular}

Table A2. The demographic determinants of preferences. For each regression a dummy variable has been created to indicate those people who choose lower risk lotteries in the three treatments. (Standard errors) have been clustered at the session level. *** indicates significant at the $1 \%, * * 5 \%$ and $* 10 \%$ levels. 


\begin{tabular}{|c|c|c|c|c|c|c|c|c|}
\hline & $\begin{array}{c}\text { Home } \\
\text { Owners hip } \\
\text { [indicator] }\end{array}$ & $\begin{array}{c}\text { Basic } \\
\text { Services } \\
{[\operatorname{Pr}(\text { all 3) }]}\end{array}$ & $\begin{array}{c}\text { Employment } \\
\text { [indicator] }\end{array}$ & $\begin{array}{c}\text { Economic } \\
\text { Class } \\
{[\operatorname{Pr}(\text { high })]}\end{array}$ & $\begin{array}{c}\text { Relative } \\
\text { Wealth } \\
\text { [unit inter val] }\end{array}$ & $\begin{array}{c}\text { Not Require } \\
\text { Assist ance } \\
\text { [indicator] }\end{array}$ & $\begin{array}{l}\text { Expenditures } \\
\text { [\# min wages] }\end{array}$ & $\begin{array}{c}\text { Not Lost } \\
\text { a Business } \\
\text { [indicator] }\end{array}$ \\
\hline Lotter y $\$ 25 \mid \$ 47$ & $\begin{array}{c}-0.045^{*} \\
(0.026)\end{array}$ & $\begin{array}{c}-0.001 \\
(0.008)\end{array}$ & $\begin{array}{c}-0.002 \\
(0.022)\end{array}$ & $\begin{array}{c}-0.001 \\
(0.014)\end{array}$ & $\begin{array}{l}0.002 \\
(0.007)\end{array}$ & $\begin{array}{l}0.046^{*} \\
(0.026)\end{array}$ & $\begin{array}{l}0.044 \\
(0.062)\end{array}$ & $\begin{array}{l}-0.001 \\
(0.011)\end{array}$ \\
\hline Lottery $\$ 18 \mid \$ 62$ & $\begin{array}{l}-0.022 \\
(0.031)\end{array}$ & $\begin{array}{l}-0.01 \\
(0.010)\end{array}$ & $\begin{array}{c}-0.047^{*} \\
(0.028)\end{array}$ & $\begin{array}{l}-0.031^{* *} \\
(0.016)\end{array}$ & $\begin{array}{l}-0.006 \\
(0.008)\end{array}$ & $\begin{array}{l}-0.024 \\
(0.034)\end{array}$ & $\begin{array}{l}-0.005 \\
(0.074)\end{array}$ & $\begin{array}{l}0.003 \\
(0.013)\end{array}$ \\
\hline Lottery $\$ 11 \mid \$ 77$ & $\begin{array}{l}-0.048 \\
(0.035)\end{array}$ & $\begin{array}{l}-0.012 \\
(0.012)\end{array}$ & $\begin{array}{l}-0.002 \\
(0.030)\end{array}$ & $\begin{array}{l}-0.025 \\
(0.018)\end{array}$ & $\begin{array}{l}-0.035^{* * *} \\
(0.010)\end{array}$ & $\begin{array}{l}0.045 \\
(0.035)\end{array}$ & $\begin{array}{l}-0.043 \\
(0.084)\end{array}$ & $\begin{array}{l}0.008 \\
(0.012)\end{array}$ \\
\hline Lotter y $\$ 4 \mid \$ 91$ & $\begin{array}{l}-0.048 \\
(0.037)\end{array}$ & $\begin{array}{l}-0.023 \\
(0.015)\end{array}$ & $\begin{array}{l}-0.001 \\
(0.034)\end{array}$ & $\begin{array}{l}0.036 \\
(0.026)\end{array}$ & $\begin{array}{l}0.014 \\
(0.014)\end{array}$ & $\begin{array}{l}0.02 \\
(0.041)\end{array}$ & $\begin{array}{l}0.044 \\
(0.108)\end{array}$ & $\begin{array}{l}-0.024 \\
(0.019)\end{array}$ \\
\hline Lott er y $\$ 0 \mid \$ 95$ & $\begin{array}{l}-0.049 \\
(0.038)\end{array}$ & $\begin{array}{l}-0.016 \\
(0.013)\end{array}$ & $\begin{array}{l}0.035 \\
(0.027)\end{array}$ & $\begin{array}{l}0.008 \\
(0.024)\end{array}$ & $\begin{array}{l}0.006 \\
(0.011)\end{array}$ & $\begin{array}{l}0.031 \\
(0.043)\end{array}$ & $\begin{array}{l}-0.049 \\
(0.093)\end{array}$ & $\begin{array}{l}0.001 \\
(0.014)\end{array}$ \\
\hline Pool Risk & $\begin{array}{l}-0.018 \\
(0.019)\end{array}$ & $\begin{array}{l}-0.005 \\
(0.005)\end{array}$ & $\begin{array}{l}0.019 \\
(0.016)\end{array}$ & $\begin{array}{l}-0.001 \\
(0.014)\end{array}$ & $\begin{array}{l}-0.003 \\
(0.006)\end{array}$ & $\begin{array}{l}-0.036 \\
(0.023)\end{array}$ & $\begin{array}{l}-0.026 \\
(0.047)\end{array}$ & $\begin{array}{l}-0.019^{* *} \\
(0.008)\end{array}$ \\
\hline Female & $\begin{array}{l}-0.010 \\
(0.020)\end{array}$ & $\begin{array}{l}-0.005 \\
(0.006)\end{array}$ & $\begin{array}{l}-0.084^{* * *} \\
(0.016)\end{array}$ & $\begin{array}{l}0.003 \\
(0.012)\end{array}$ & $\begin{array}{l}0.005 \\
(0.006)\end{array}$ & $\begin{array}{l}0.028 \\
(0.022)\end{array}$ & $\begin{array}{l}0.020 \\
(0.049)\end{array}$ & $\begin{array}{l}0.019^{* *} \\
(0.008)\end{array}$ \\
\hline Age & $\begin{array}{l}0.003^{* * *} \\
(0.001)\end{array}$ & $\begin{array}{l}0.001 \\
(0.003)\end{array}$ & $\begin{array}{l}0.003^{* * *} \\
(0.001)\end{array}$ & $\begin{array}{l}-0.001 \\
(0.007)\end{array}$ & $\begin{array}{l}-0.002^{* * *} \\
(0.000)\end{array}$ & $\begin{array}{l}0.001 \\
(0.001)\end{array}$ & $\begin{array}{l}-0.005 \\
(0.002)\end{array}$ & $\begin{array}{l}-0.001^{* * *} \\
(0.000)\end{array}$ \\
\hline College & $\begin{array}{l}0.026 \\
(0.064)\end{array}$ & $\begin{array}{l}0.039^{* * *} \\
(0.006)\end{array}$ & $\begin{array}{l}0.139^{* *} \\
(0.022)\end{array}$ & $\begin{array}{l}0.428^{* * *} \\
(0.064)\end{array}$ & $\begin{array}{l}0.135^{* * *} \\
(0.023)\end{array}$ & $\begin{array}{l}0.025 \\
(0.105)\end{array}$ & $\begin{array}{l}1.197^{* * *} \\
(0.123)\end{array}$ & $\begin{array}{l}0.039 \\
(0.014)\end{array}$ \\
\hline Ma rried & $\begin{array}{l}0.011 \\
(0.020)\end{array}$ & $\begin{array}{l}0.016^{* * *} \\
(0.006)\end{array}$ & $\begin{array}{l}0.029 \\
(0.019)\end{array}$ & $\begin{array}{l}0.053^{* * *} \\
(0.018)\end{array}$ & $\begin{array}{l}0.043^{* * *} \\
(0.008)\end{array}$ & $\begin{array}{l}0.076^{* * *} \\
(0.024)\end{array}$ & $\begin{array}{l}0.467^{* * *} \\
(0.056)\end{array}$ & $\begin{array}{l}0.009 \\
(0.009)\end{array}$ \\
\hline Children & $\begin{array}{l}-0.026^{* * *} \\
(0.009)\end{array}$ & $\begin{array}{l}-0.016^{* * *} \\
(0.003)\end{array}$ & $\begin{array}{l}-0.003 \\
(0.007)\end{array}$ & $\begin{array}{l}-0.046^{* * *} \\
(0.007)\end{array}$ & $\begin{array}{l}-0.02^{* * *} \\
(0.003)\end{array}$ & $\begin{array}{l}-0.088^{* * *} \\
(0.010)\end{array}$ & $\begin{array}{l}-0.108^{* * *} \\
(0.023)\end{array}$ & $\begin{array}{l}-0.006^{* *} \\
(0.003)\end{array}$ \\
\hline Indian Herit age & $\begin{array}{l}0.044 \\
(0.072)\end{array}$ & $\begin{array}{l}0.001 \\
(0.023)\end{array}$ & $\begin{array}{l}0.001 \\
(0.063)\end{array}$ & $\begin{array}{l}-0.022 \\
(0.043)\end{array}$ & $\begin{array}{l}-0.057^{* * *} \\
(0.017)\end{array}$ & $\begin{array}{l}0.019 \\
(0.063)\end{array}$ & $\begin{array}{l}-0.195 \\
(0.145)\end{array}$ & $\begin{array}{c}0.044^{* *} \\
(0.010)\end{array}$ \\
\hline African $\mathrm{H}$ eritage & $\begin{array}{l}-0.035 \\
(0.055)\end{array}$ & $\begin{array}{l}-0.002 \\
(0.014)\end{array}$ & $\begin{array}{l}0.006 \\
(0.058)\end{array}$ & $\begin{array}{l}-0.079^{* * *} \\
(0.025)\end{array}$ & $\begin{array}{l}-0.057^{* * *} \\
(0.020)\end{array}$ & $\begin{array}{l}-0.044 \\
(0.066)\end{array}$ & $\begin{array}{l}-0.109 \\
(0.131)\end{array}$ & $\begin{array}{l}0.043^{*} \\
(0.011)\end{array}$ \\
\hline Home Size & $\begin{array}{l}0.113^{* * *} \\
(0.012)\end{array}$ & $\begin{array}{l}0.025^{* * *} \\
(0.005)\end{array}$ & $\begin{array}{l}-0.024^{* * *} \\
(0.008)\end{array}$ & $\begin{array}{l}0.037^{* * *} \\
(0.007)\end{array}$ & $\begin{array}{l}0.025^{* * *} \\
(0.004)\end{array}$ & $\begin{array}{l}-0.033^{* * *} \\
(0.013)\end{array}$ & $\begin{array}{l}0.263^{* * *} \\
(0.031)\end{array}$ & $\begin{array}{l}0.001 \\
(0.004)\end{array}$ \\
\hline Income Ear ners & $\begin{array}{l}0.033^{* * *} \\
(0.013)\end{array}$ & $\begin{array}{l}0.002 \\
(0.005)\end{array}$ & $\begin{array}{l}0.071^{* * *} \\
(0.010)\end{array}$ & $\begin{array}{l}0.020^{* * *} \\
(0.007)\end{array}$ & $\begin{array}{l}0.010^{* * *} \\
(0.003)\end{array}$ & $\begin{array}{l}0.030^{* * *} \\
(0.012)\end{array}$ & $\begin{array}{l}0.109^{* * *} \\
(0.030)\end{array}$ & $\begin{array}{l}(0.003) \\
(0.004)\end{array}$ \\
\hline No Access to Credit & $\begin{array}{l}-0.053^{* *} \\
(0.022)\end{array}$ & $\begin{array}{l}-0.011 \\
(0.008)\end{array}$ & $\begin{array}{l}-0.007 \\
(0.017)\end{array}$ & $\begin{array}{l}-0.039^{* * *} \\
(0.014)\end{array}$ & $\begin{array}{l}-0.030^{* * *} \\
(0.007)\end{array}$ & $\begin{array}{l}-0.100^{* * *} \\
(0.027)\end{array}$ & $\begin{array}{l}-0.148^{* *} \\
(0.064)\end{array}$ & $\begin{array}{l}-0.046^{* * *} \\
(0.011)\end{array}$ \\
\hline No Access to Politics & $\begin{array}{l}0.035 \\
(0.052)\end{array}$ & $\begin{array}{l}-0.023 \\
(0.017)\end{array}$ & $\begin{array}{l}-0.062 \\
(0.045)\end{array}$ & $\begin{array}{l}-0.002 \\
(0.027)\end{array}$ & $\begin{array}{l}0.007 \\
(0.015)\end{array}$ & $\begin{array}{l}-0.087 \\
(0.062)\end{array}$ & $\begin{array}{l}0.121 \\
(0.109)\end{array}$ & $\begin{array}{l}-0.018 \\
(0.021)\end{array}$ \\
\hline Observations & 3088 & 3088 & 2170 & 3083 & 3087 & 2418 & 2811 & 3088 \\
\hline Psuedo R-Squared & 0.095 & 0.170 & 0.082 & 0.058 & 0.050 & 0.180 & 0.078 & 0.066 \\
\hline
\end{tabular}

Table A3. Simple risk and well-being. Each column represents the regression of a different well-being measure on the set of independent variables. Each regression includes unreported location fixed effects. (Standard errors) are clustered at the session level. *** indicates significant at the $1 \%, * * 5 \%$ and $* 10 \%$ levels. 


\begin{tabular}{|c|c|c|c|c|c|c|c|c|}
\hline & $\begin{array}{c}\text { Home } \\
\text { Owners hip } \\
\text { [indicator] }\end{array}$ & $\begin{array}{c}\text { Basic } \\
\text { Services } \\
{[\operatorname{Pr}(\text { all 3) }]}\end{array}$ & $\begin{array}{l}\text { Employment } \\
\text { [indicator] }\end{array}$ & $\begin{array}{c}\text { Economic } \\
\text { Class } \\
{[\operatorname{Pr}(\text { high })]}\end{array}$ & $\begin{array}{c}\text { Relative } \\
\text { Wealth } \\
\text { [unit interval] }\end{array}$ & $\begin{array}{l}\text { Not Require } \\
\text { Assistance } \\
\text { [indicator] }\end{array}$ & $\begin{array}{l}\text { Expenditures } \\
\text { [\# min wages] }\end{array}$ & $\begin{array}{l}\text { Not Lost } \\
\text { a Business } \\
\text { [indicator] }\end{array}$ \\
\hline Ambiguity - Risk & $\begin{array}{l}0.009 \\
(0.012)\end{array}$ & $\begin{array}{l}0.007^{* *} \\
(0.003)\end{array}$ & $\begin{array}{l}-0.007 \\
(0.010)\end{array}$ & $\begin{array}{l}-0.003 \\
(0.007)\end{array}$ & $\begin{array}{l}0.053 \\
(0.037)\end{array}$ & $\begin{array}{c}-0.012 \\
(0.013)\end{array}$ & $\begin{array}{l}0.011 \\
(0.028)\end{array}$ & $\begin{array}{l}-0.004 \\
(0.005)\end{array}$ \\
\hline $\max \{$ Ambiguity - Risk, 0$\}$ & $\begin{array}{l}-0.009 \\
(0.019)\end{array}$ & $\begin{array}{l}-0.010^{* *} \\
(0.005)\end{array}$ & $\begin{array}{l}0.018 \\
(0.016)\end{array}$ & $\begin{array}{l}0.001 \\
(0.011)\end{array}$ & $\begin{array}{l}-0.002 \\
(0.062)\end{array}$ & $\begin{array}{l}-0.007 \\
(0.019)\end{array}$ & $\begin{array}{l}-0.022 \\
(0.041)\end{array}$ & $\begin{array}{l}-0.009 \\
(0.007)\end{array}$ \\
\hline Loss - Risk & $\begin{array}{l}-0.036^{* * *} \\
(0.012)\end{array}$ & $\begin{array}{l}-0.004 \\
(0.003)\end{array}$ & $\begin{array}{l}-0.009 \\
(0.011)\end{array}$ & $\begin{array}{l}0.009 \\
(0.008)\end{array}$ & $\begin{array}{l}-0.059^{*} \\
(0.035)\end{array}$ & $\begin{array}{l}0.015 \\
(0.013)\end{array}$ & $\begin{array}{l}-0.003 \\
(0.030)\end{array}$ & $\begin{array}{l}-0.001 \\
(0.005)\end{array}$ \\
\hline $\max \{$ Loss - Risk, 0$\}$ & $\begin{array}{l}0.033^{* *} \\
(0.015)\end{array}$ & $\begin{array}{l}0.003 \\
(0.004)\end{array}$ & $\begin{array}{l}0.010 \\
(0.014)\end{array}$ & $\begin{array}{l}-0.012 \\
(0.011)\end{array}$ & $\begin{array}{l}0.006 \\
(0.045)\end{array}$ & $\begin{array}{l}-0.014 \\
(0.018)\end{array}$ & $\begin{array}{l}-0.043 \\
(0.041)\end{array}$ & $\begin{array}{l}-0.004 \\
(0.007)\end{array}$ \\
\hline Pooling - Risk & $\begin{array}{l}0.014 \\
(0.012)\end{array}$ & $\begin{array}{l}0.006^{*} \\
(0.003)\end{array}$ & $\begin{array}{l}0.012 \\
(0.010)\end{array}$ & $\begin{array}{l}0.012^{*} \\
(0.007)\end{array}$ & $\begin{array}{l}0.091^{* * *} \\
(0.036)\end{array}$ & $\begin{array}{l}0.016^{* *} \\
(0.010)\end{array}$ & $\begin{array}{l}0.061^{* *} \\
(0.030)\end{array}$ & $\begin{array}{l}0.002 \\
(0.004)\end{array}$ \\
\hline $\max \{$ Pooling - Risk, 0$\}$ & $\begin{array}{l}-0.011 \\
(0.017)\end{array}$ & $\begin{array}{l}-0.011^{* *} \\
(0.005)\end{array}$ & $\begin{array}{l}-0.028^{* *} \\
(0.014)\end{array}$ & $\begin{array}{l}-0.022^{* *} \\
(0.010)\end{array}$ & $\begin{array}{c}-0.085^{*} \\
(0.053)\end{array}$ & $\begin{array}{l}-0.009 \\
(0.019)\end{array}$ & $\begin{array}{l}-0.042 \\
(0.044)\end{array}$ & $\begin{array}{l}-0.004 \\
(0.006)\end{array}$ \\
\hline Pool Risk & $\begin{array}{l}-0.019 \\
(0.020)\end{array}$ & $\begin{array}{l}-0.002 \\
(0.005)\end{array}$ & $\begin{array}{l}0.021 \\
(0.015)\end{array}$ & $\begin{array}{l}0.001 \\
(0.014)\end{array}$ & $\begin{array}{l}0.030 \\
(0.058)\end{array}$ & $\begin{array}{l}-0.035 \\
(0.024)\end{array}$ & $\begin{array}{l}0.018 \\
(0.048)\end{array}$ & $\begin{array}{l}-0.016^{* *} \\
(0.008)\end{array}$ \\
\hline Female & $\begin{array}{l}-0.011 \\
(0.020)\end{array}$ & $\begin{array}{l}-0.004 \\
(0.006)\end{array}$ & $\begin{array}{l}-0.086^{* * *} \\
(0.015)\end{array}$ & $\begin{array}{l}0.002 \\
(0.012)\end{array}$ & $\begin{array}{l}0.050 \\
(0.055)\end{array}$ & $\begin{array}{l}0.031 \\
(0.021)\end{array}$ & $\begin{array}{l}0.026 \\
(0.048)\end{array}$ & $\begin{array}{l}0.020 * * * \\
(0.008)\end{array}$ \\
\hline Age & $\begin{array}{l}0.003^{* * *} \\
(0.001)\end{array}$ & $\begin{array}{l}0.001 \\
(0.001)\end{array}$ & $\begin{array}{l}0.003^{\text {*** }} \\
(0.001)\end{array}$ & $\begin{array}{l}-0.001 \\
(0.001)\end{array}$ & $\begin{array}{l}-0.016^{* * *} \\
(0.003)\end{array}$ & $\begin{array}{l}-0.001 \\
(0.001)\end{array}$ & $\begin{array}{l}-0.005^{* *} \\
(0.002)\end{array}$ & $\begin{array}{l}-0.001^{* * * *} \\
(0.001)\end{array}$ \\
\hline College & $\begin{array}{l}0.024 \\
(0.065)\end{array}$ & $\begin{array}{l}0.038^{* * *} \\
(0.006)\end{array}$ & $\begin{array}{l}0.139^{* *} \\
(0.023)\end{array}$ & $\begin{array}{l}0.421^{* * *} \\
(0.064)\end{array}$ & $\begin{array}{l}1.332^{* * *} \\
(0.227)\end{array}$ & $\begin{array}{l}0.022 \\
(0.110)\end{array}$ & $\begin{array}{l}1.187^{* * *} \\
(0.124)\end{array}$ & $\begin{array}{l}0.038 \\
(0.015)\end{array}$ \\
\hline Married & $\begin{array}{l}0.011 \\
(0.020)\end{array}$ & $\begin{array}{l}0.016^{\text {*** }} \\
(0.006)\end{array}$ & $\begin{array}{l}0.030 \\
(0.019)\end{array}$ & $\begin{array}{l}0.053^{* * *} \\
(0.018)\end{array}$ & $\begin{array}{l}0.439^{* * *} \\
(0.080)\end{array}$ & $\begin{array}{l}0.076^{* * *} \\
(0.024)\end{array}$ & $\begin{array}{l}0.466^{* * *} \\
(0.055)\end{array}$ & $\begin{array}{l}0.008 \\
(0.009)\end{array}$ \\
\hline Children & $\begin{array}{l}-0.027^{* * *} \\
(0.009)\end{array}$ & $\begin{array}{l}-0.016^{* * *} \\
(0.003)\end{array}$ & $\begin{array}{l}-0.005 \\
(0.007)\end{array}$ & $\begin{array}{l}-0.045^{* * *} \\
(0.007)\end{array}$ & $\begin{array}{l}-0.285^{* * *} \\
(0.027)\end{array}$ & $\begin{array}{l}-0.088^{* * *} \\
(0.010)\end{array}$ & $\begin{array}{l}-0.105^{* * *} \\
(0.023)\end{array}$ & $\begin{array}{l}-0.006^{* *} \\
(0.003)\end{array}$ \\
\hline Indian Heritage & $\begin{array}{l}0.047 \\
(0.072)\end{array}$ & $\begin{array}{l}0.005 \\
(0.023)\end{array}$ & $\begin{array}{l}0.004 \\
(0.065)\end{array}$ & $\begin{array}{l}-0.021 \\
(0.044)\end{array}$ & $\begin{array}{l}-0.575^{* * *} \\
(0.165)\end{array}$ & $\begin{array}{l}0.013 \\
(0.065)\end{array}$ & $\begin{array}{l}-0.199 \\
(0.145)\end{array}$ & $\begin{array}{l}0.043^{*} \\
(0.010)\end{array}$ \\
\hline African Heritage & $\begin{array}{l}-0.031 \\
(0.055)\end{array}$ & $\begin{array}{l}-0.001 \\
(0.013)\end{array}$ & $\begin{array}{l}-0.003 \\
(0.061)\end{array}$ & $\begin{array}{l}-0.082^{* * *} \\
(0.024)\end{array}$ & $\begin{array}{l}-0.549^{* * *} \\
(0.195)\end{array}$ & $\begin{array}{l}-0.047 \\
(0.065)\end{array}$ & $\begin{array}{l}-0.092 \\
(0.131)\end{array}$ & $\begin{array}{l}0.043^{*} \\
(0.011)\end{array}$ \\
\hline Home Size & $\begin{array}{l}0.113^{\text {*** }} \\
(0.012)\end{array}$ & $\begin{array}{l}0.024^{\text {*** }} \\
(0.005)\end{array}$ & $\begin{array}{l}-0.025^{* * *} \\
(0.008)\end{array}$ & $\begin{array}{l}0.037^{* * *} \\
(0.008)\end{array}$ & $\begin{array}{l}0.246^{* * *} \\
(0.035)\end{array}$ & $\begin{array}{l}-0.033^{* *} \\
(0.014)\end{array}$ & $\begin{array}{l}0.262^{* * *} \\
(0.031)\end{array}$ & $\begin{array}{l}0.001 \\
(0.004)\end{array}$ \\
\hline Income Earners & $\begin{array}{l}0.034^{\text {*** }} \\
(0.012)\end{array}$ & $\begin{array}{l}-0.002 \\
(0.004)\end{array}$ & $\begin{array}{l}0.071^{* * *} \\
(0.010)\end{array}$ & $\begin{array}{l}0.019^{* * *} \\
(0.007)\end{array}$ & $\begin{array}{l}0.101^{* * *} \\
(0.030)\end{array}$ & $\begin{array}{l}0.029^{* *} \\
(0.012)\end{array}$ & $\begin{array}{l}0.107^{* * *} \\
(0.030)\end{array}$ & $\begin{array}{l}-0.003 \\
(0.004)\end{array}$ \\
\hline No Access to Credit & $\begin{array}{l}-0.054^{* * *} \\
(0.022)\end{array}$ & $\begin{array}{l}-0.011 \\
(0.008)\end{array}$ & $\begin{array}{l}-0.005 \\
(0.018)\end{array}$ & $\begin{array}{l}-0.037^{* * *} \\
(0.014)\end{array}$ & $\begin{array}{l}-0.317^{* * *} \\
(0.069)\end{array}$ & $\begin{array}{l}-0.100^{* * *} \\
(0.027)\end{array}$ & $\begin{array}{l}-0.154^{* *} \\
(0.064)\end{array}$ & $\begin{array}{l}-0.046^{* * *} \\
(0.011)\end{array}$ \\
\hline No Access to Politics & $\begin{array}{l}-0.031 \\
(0.051)\end{array}$ & $\begin{array}{l}-0.025 \\
(0.017)\end{array}$ & $\begin{array}{l}-0.060 \\
(0.044)\end{array}$ & $\begin{array}{l}-0.003 \\
(0.028)\end{array}$ & $\begin{array}{l}-0.013 \\
(0.150)\end{array}$ & $\begin{array}{l}-0.078 \\
(0.062)\end{array}$ & $\begin{array}{l}0.118 \\
(0.110)\end{array}$ & $\begin{array}{l}-0.015 \\
(0.020)\end{array}$ \\
\hline $\mathrm{R}^{2}$ or pseudo $\mathrm{R}^{2}$ & 0.096 & 0.178 & 0.081 & 0.058 & 0.050 & 0.181 & 0.079 & 0.069 \\
\hline $\mathrm{p}$-value from $\mathrm{Chi}^{2}$ or $\mathrm{F}$ test & $<0.01$ & $<0.01$ & $<0.01$ & $<0.01$ & $<0.01$ & $<0.01$ & $<0.01$ & $<0.01$ \\
\hline Observations & 3087 & 3087 & 2169 & 3082 & 3086 & 2418 & 2810 & 3087 \\
\hline
\end{tabular}

Table A4. Treatment differences and well-being. Each column refers to a different aspect of well-being. The regressions are splines to allow reactions to differ depending on whether or not one reacts more or less conservatively to the treatments. The splines are estimated with either OLS, Probit, Ordered Probit or Tobit depending on the restrictions on the dependent variable. All regressions include location fixed effects. The standard errors (in parentheses) are clustered at the session level. Marginal effects are reported instead of coefficients. ***, $* *, *$ indicate significant at the $1 \%, 5 \%$ and $10 \%$ levels. 